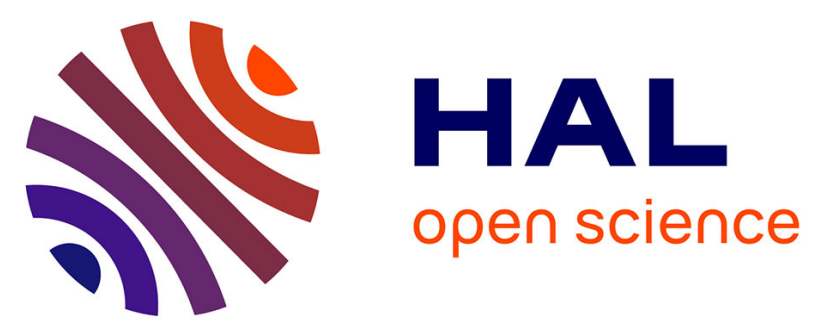

\title{
Palladium(ii) complexes of tetradentate donor-acceptor Schiff base ligands: synthesis and spectral, structural, thermal and NLO properties
}

Salvador Celedon, Thierry Roisnel, Vania Artigas, Mauricio Fuentealba, David Carrillo, Isabelle Ledoux-Rak, Jean-René Hamon, Carolina Manzur

\section{To cite this version:}

Salvador Celedon, Thierry Roisnel, Vania Artigas, Mauricio Fuentealba, David Carrillo, et al.. Palladium(ii) complexes of tetradentate donor-acceptor Schiff base ligands: synthesis and spectral, structural, thermal and NLO properties. New Journal of Chemistry, 2020, 44 (22), pp.9190-9201. 10.1039/d0nj01982h . hal-02928522

\section{HAL Id: hal-02928522 \\ https://hal.science/hal-02928522}

Submitted on 17 Sep 2020

HAL is a multi-disciplinary open access archive for the deposit and dissemination of scientific research documents, whether they are published or not. The documents may come from teaching and research institutions in France or abroad, or from public or private research centers.
L'archive ouverte pluridisciplinaire HAL, est destinée au dépôt et à la diffusion de documents scientifiques de niveau recherche, publiés ou non, émanant des établissements d'enseignement et de recherche français ou étrangers, des laboratoires publics ou privés. 


\title{
Palladium (II) complexes of tetradentate donor-acceptor Schiff base ligands: synthesis, spectral, structural, thermal and NLO properties ${ }^{\dagger}$
}

\author{
Salvador Celedón, *a,\# Thierry Roisnel, ${ }^{b}$ Vania Artigas, ${ }^{c}$ Mauricio Fuentealba,c \\ David Carrillo, ${ }^{a}$ Isabelle Ledoux-Rak, ${ }^{d}$ Jean-René Hamon*, b and Carolina Manzur*a ${ }^{a}$
}

a Laboratorio de Química Inorgánica, Instituto de Química, Facultad de Ciencias, Pontificia Universidad Católica de Valparaíso, Avenida Universidad 330, Curauma, Valparaíso,Chile.E-mail: cecilia.manzur@pucv.cl

b Univ Rennes, CNRS, ISCR (Institut des Sciences Chimiques de Rennes) - UMR 6226, F35000 Rennes, France. E-mail: jean-rene.hamon@univ-rennes1.fr

c Laboratorio de Cristalografía, Instituto de Química, Facultad de Ciencias, Pontificia Universidad Católica de Valparaíso, Avenida Universidad 330, Curauma, Valparaíso, Chile.

d Laboratoire Lumière, Matière et Interfaces, FRE 2036 CNRS 8537, ENS Paris Saclay, Institut d'Alembert, 4 Avenue des Sciences 91190 Gif-sur-Yvette, France.

\# Present address: Instituto de Ciencias Naturales, Universidad de las Américas, Manuel Montt 948, Santiago, Chile.E-mail: scelednp@edu.udla.cl

$\dagger \quad$ Electronic supplementary information (ESI) available: CCDC 1996185 and 1995018. For ESI and crystallographic data in CIF or other electronic format see DOI: 


\section{Abstract}

This report explores the synthesis, spectral, structural, thermal, electrochemical, linear and nonlinear (NLO) properties of unsymmetrically-substituted $\mathrm{N}_{2} \mathrm{O}_{2}$ tetradentate Schiff base proligand and related - bi and trimetallic $\mathrm{Pd}^{\mathrm{II}}$ complexes. The diprotic proligand $\mathrm{Fc}-$ $\mathrm{C}(=\mathrm{O}) \mathrm{CH}=\mathrm{C}\left(4-\mathrm{C}_{6} \mathrm{H}_{4} \mathrm{OH}\right) \mathrm{NH}-\mathrm{CH}_{2} \mathrm{CH}_{2} \mathrm{~N}=\mathrm{CH}-\left(2-\mathrm{OH}, 4-\mathrm{CO}_{2} \mathrm{H}-\mathrm{C}_{6} \mathrm{H}_{3}\right)\left(2, \mathrm{Fc}=\right.$ ferrocenyl $=\left(\eta^{5}-\right.$ $\left.\left.\left.\mathrm{C}_{5} \mathrm{H}_{5}\right) \mathrm{Fe}\left(\eta^{5}-\mathrm{C}_{5} \mathrm{H}_{4}\right)\right)\right)$, is synthetized by condensation of the 4-hydroxyphenyl-appended ferrocenylenaminone 1 with 4-formyl-3-hydroxybenzoic acid. The related Pd(II) complexes, neutral bimetallic 3 and ionic trimetallic 4 , were both prepared via a three-component one-pot template reaction involving the half unit $\mathbf{1}$, palladium acetate, the $\mathrm{CO}_{2} \mathrm{H}$-functionalized salicylaldehyde and the organometallic salicylaldehyde $\left[\mathrm{Cp}^{*} \mathrm{Ru}\left(\eta^{6}-2-\mathrm{OH}-\mathrm{C}_{6} \mathrm{H}_{4} \mathrm{CHO}\right)\right] \mathrm{PF}_{6}$, respectively $\left(\mathrm{Cp}^{*}=\eta^{5}-\mathrm{C}_{5} \mathrm{Me}_{5}\right)$. Compounds $\mathbf{2 - 4}$ were isolated as colored air and thermally stable solids in 74-86\% yields. They were thoroughly characterized using various physicochemical tools, such as $\mathrm{CHN}$ analyses, IR, UV-vis, ${ }^{1} \mathrm{H}$ and ${ }^{13} \mathrm{C}$ NMR spectroscopy, TGA and cyclic voltammetry. The molecular structures of $\mathbf{3}$ and $\mathbf{4}$ were authenticated by singlecrystal X-ray diffraction methods. In both $\mathbf{3}$ and $\mathbf{4}$, the four-coordinate palladium atom adopts a square planar geometry with two nitrogen and two oxygen atoms as donors occupying cis positions. Additionally in $\mathbf{4}$, the ferrocenyl and $\mathrm{Cp}^{*} \mathrm{Ru}^{+}$moieties exhibit an anti-conformation with respect to the $\left[\mathrm{Pd}\left(\mathrm{N}_{2} \mathrm{O}_{2}\right]\right.$ Schiff base platform. The electrochemical behavior of the two Pd(II) complexes was investigated by cyclic voltammetry, showing in both cases a reversible redox process ascribed to the $\mathrm{Fe}(\mathrm{II}) / \mathrm{Fe}$ (III) couple of the dangling donor ferrocene. Compared to that for $\mathbf{3}$, the oxidation wave for $\mathbf{4}$ is anodically shifted by $30 \mathrm{mV}$, evidencing a greater electron accepting ability of $\mathrm{Cp}^{*} \mathrm{Ru}^{+} v s-\mathrm{CO}_{2} \mathrm{H}$. The second-order NLO responses of the pushpull derivatives 2-4 have been determined by harmonic light scattering measurements in N,Ndimethylformamide solutions at $1.91 \mu \mathrm{m}$ incident wavelength, and rather good quadratic hyperpolarisability $\beta$ values ranging from $120-160 \times 10^{-30}$ esu were determined. 


\section{Introduction}

Schiff base compounds are among the most widely used proligands in the preparation of stable and functional coordination complexes. ${ }^{1,2}$ They are characterized by an imine $(>\mathrm{C}=\mathrm{N}-)$ or azomethine $(-\mathrm{HC}=\mathrm{N}-)$ function. Most Schiff bases are easily accessible using simple synthetic procedures and by selecting suitable condensing carbonyl and primary amine reagents, tunable control over the nature of donor atoms, denticity, chelating ability, and stereoelectronic structures could be achieved. ${ }^{2,3}$ Another major advantage of Schiff bases is that they can stabilize metals in various oxidation states. ${ }^{4}$ Consequently, Schiff base complexes have raised interest in various fields of research and found applications in many areas, including catalysis, ${ }^{5}$ molecular magnetism, ${ }^{6}$ spin crossover, ${ }^{7}$ sensing, ${ }^{8}$ nonlinear optical (NLO) molecular materials, ${ }^{9-12}$ porous ${ }^{13}$ and energy materials, ${ }^{14}$ as well as for their properties in biological, pharmacological and medicinal chemistry. ${ }^{15-19}$ In this regard, palladium(II) complexes with Schiff base ligands have been intensively investigated due to their applications in catalysis and in a wide variety of biological reactions. They have indeed been used as homogeneous and heterogeneous catalysts, especially in Suzuki-Miyaura cross coupling reaction, ${ }^{20-22}$ and as antiviral, anti-fungal, anti-microbial and anti-tumor bioinorganic agents, ${ }^{23-28}$ respectively. In contrast, less research has been reported regarding palladium complexes supported with Schiff base ligands as chromophores in the field of NLO materials. ${ }^{29-32}$

Organic compounds presenting high second-order NLO responses (molecular hyperpolarizability, $\beta$ ) are generally made of electron-donor group (D) and electron-acceptor group (A) linked through a $\pi$-conjugated system to form a D- $\pi$-A dipolar push-pull structure. ${ }^{33}$ They show effective intramolecular charge transfer from the donor to the acceptor, featuring low-energy and intense charge transfer absorptions. In this context, coordination complexes represent a fascinating and growing class of second-order NLO chromophores due to the presence of metal-ligand charge-transfer transitions which are tunable by virtue of the nature, oxidation states, and coordination sphere of the metal centers. ${ }^{9-12,34-37}$

Interestingly, the highly modular synthesis of unsymmetrically-substituted $\mathrm{N}_{2} \mathrm{O}_{2}$ tetradentate Schiff base proligands allows the facile preparation of dipolar D- $\pi$-A structures where the metal is part of the polarized bridge. ${ }^{38}$ They are obtained via a multicomponent template synthesis involving $\beta$-diketone, primary diamine, salicylaldehyde or its derivatives and the metal salt in the 1:1:1:1 stoichiometric ratio. ${ }^{39}$ However, mono-condensed Schiff base proligands, so-called half-units, ${ }^{40}$ have also been obtained upon condensation of carbonyl and diamine substrates, yielding a large variety of tridentate proligands featuring $\mathrm{O}, \mathrm{N}, \mathrm{N}-$ donor 
set. $^{38,39}$ In 2012, we applied this procedure to 4-(4-hydroxyphenyl)-ferrocenoylacetone to synthetize the corresponding organometallic enaminone "half-unit" $\mathrm{Fc}-\mathrm{C}(=\mathrm{O}) \mathrm{CH}=\mathrm{C}(4-$ $\left.\mathrm{C}_{6} \mathrm{H}_{4} \mathrm{OH}\right) \mathrm{N}(\mathrm{H}) \mathrm{CH}_{2} \mathrm{CH}_{2} \mathrm{NH}_{2}\left(1, \mathrm{Fc}=\left(\eta^{5}-\mathrm{C}_{5} \mathrm{H}_{5}\right) \mathrm{Fe}\left(\eta^{5}-\mathrm{C}_{5} \mathrm{H}_{4}\right)\right.$, Scheme 1$) .{ }^{41}$ This compound containing the electron releasing ferrocenyl moiety $(\mathrm{Fc})$ has been condensed with salicylaldehydes substituted with different electron withdrawing groups $\left(\mathrm{CO}_{2} \mathrm{H}, \mathrm{NO} 2, \mathrm{Cp}^{*} \mathrm{Ru}^{+}\right.$ $\left.\left(\mathrm{Cp}^{*}=\eta^{5}-\mathrm{C}_{5} \mathrm{Me}_{5}\right)\right)$ in the presence of divalent metal ions $(\mathrm{Ni}, \mathrm{Cu}, \mathrm{Pd})$ to form either neutral bimetallic $(\mathrm{Fe} / \mathrm{Ni}, \mathrm{Fe} / \mathrm{Cu}, \mathrm{Fe} / \mathrm{Pd})^{32,37 b}$ or ionic trimetallic $\left(\mathrm{Fe} / \mathrm{Ni} / \mathrm{Ru}^{+}\right)^{42}$ complexes of $\mathrm{N}_{2} \mathrm{O}_{2}-$ tetradentate asymmetric Schiff base ligands. Depending on the nature of functional groups on the complexes, trans-esterification reaction or grafting onto polyacrylic acid led to main-chain oligomers $^{37 \mathrm{~b}}$ and side-chain metallopolymers, ${ }^{32,42}$ respectively, showing very remarkable second-order NLO responses.

Based on the abovementioned work and with the expectation of further enhancing the second-order NLO responses, we were interested in reacting the metalloproligand $\mathbf{1}$ with salicylaldehydes bearing strong electron-withdrawing substituents such as $-\mathrm{CO}_{2} \mathrm{H}$ and $\mathrm{Cp}^{*} \mathrm{Ru}^{+}$ to prepare, via Palladium(II)-assisted template synthesis, new D- $\pi$-A organometallic-inorganic hybrids and to study their structural, electronic and NLO properties. In the present study, we report on the thorough investigation, including synthesis, analytical and spectroscopic characterization, and electrochemical behavior of the new $\mathrm{N}_{2} \mathrm{O}_{2}$-tetradentate Schiff base proligand 2 resulting from the Schiff condensation of the organometallic enaminone 1 with 4formyl-3-hydroxybenzoic acid, its corresponding neutral palladium (II) complex $\mathbf{3}$, and of the ionic palladium (II)-centered trimetallic derivative 4. In 3 the salicylidene ring bears the acid functionality at the 4-position whereas in $\mathbf{4}$ it is $\eta^{6}$-coordinated to the cationic $\mathrm{Cp}^{*} \mathrm{Ru}^{+}$ arenophile (see formulas in Scheme 1). The X-ray crystal structure and thermal behavior of the two Schiff base $\mathrm{Pd}(\mathrm{II})$ complexes, along with linear and nonlinear optical properties of the three compounds are also discussed. Second-order NLO responses were determined from Harmonic Light Scattering (HLS) experiments.

\section{Results and discussion}

\section{Synthesis and spectroscopic characterization}

The diprotic unsymmetrically-substituted tetradentate Schiff base proligand $\mathbf{2}$ was readily prepared by Schiff condensation reaction between the ferrocenyl-containing half-unit $\mathbf{1}$ and an equimolar amount of 4-formyl-3-hydroxybenzoic acid in refluxing ethanol for $2 \mathrm{~h}$ (Scheme 1). Compound 2 was isolated as a red solid product in $83 \%$ yields. On the other hand, 
the $\mathrm{Pd}(\mathrm{II})$ complexes $\mathbf{3}$ and $\mathbf{4}$ supported by unsymmetrically-substituted Schiff base ligands were prepared by a one-pot template procedure, ${ }^{43,44}$ because it gives better yields than the reaction between proligand $\mathbf{2}$ and the Pd(II) salt. Thus, half-unit $\mathbf{1}$ was reacted with palladium (II) acetate and 4-formyl-3-hydroxybenzoic acid or the $\pi$-complexed salicylaldehyde $\left[\mathrm{Cp} * \mathrm{Ru}\left(\eta^{6}-2-\mathrm{OH}-\mathrm{C}_{6} \mathrm{H}_{4} \mathrm{CHO}\right)\right] \mathrm{PF}_{6},{ }^{45}$ in refluxing ethanol for $2 \mathrm{~h}$ to provide either the neutral bimetallic complex 3 or the ionic trimetallic derivative 4 (Scheme 1). Both complexes precipitated directly from the reaction mixture and were collected by filtration as yellow and red microcrystalline products isolated in $86 \%$ and $74 \%$ yield, respectively. The air and thermally stable compounds 2-4 are moisture insensitive, show good solubility in THF, DMF and DMSO, are poorly soluble in alcohols and insoluble in diethyl ether and hydrocarbons. The compositions and identities of the three new compounds 2-4 were established based on satisfactory elemental analysis, FT-IR and ${ }^{1} \mathrm{H}$ and ${ }^{13} \mathrm{C}$ multidimensional NMR spectroscopy. Additionally, the crystal and molecular structures of the two $\operatorname{Pd}(\mathrm{II})$-containing complexes $\mathbf{3}$ and 4 were determined by single-crystal X-ray diffraction analysis.

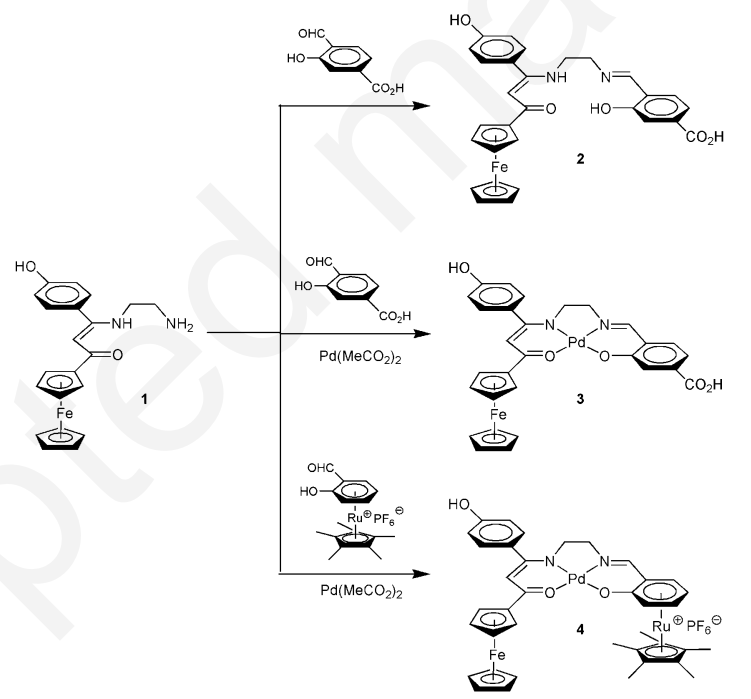

Scheme 1 Synthesis of the asymmetric Schiff base compounds 2-4. All reactions are carried out in refluxing ethanol for $2 \mathrm{~h}$.

The solid-state FT-IR spectra (KBr pellets) of compounds 2-4 (Fig. S1, ESI ${ }^{\dagger}$ ) exhibit all the characteristic set of weak, medium or strong intensity band pattern around $1610 \mathrm{~cm}^{-1}$ that can be attributed to the $v(\mathrm{C} \cdots \mathrm{O}), v(\mathrm{C} \cdots \mathrm{C})$ and/or $v(\mathrm{C} \cdots \mathrm{N})$ stretching vibrations of the organic Schiff base skeleton. ${ }^{43}$ The typical phenolic $v(\mathrm{O}-\mathrm{H})$ band, appearing in the $3444-3360 \mathrm{~cm}^{-1}$ region, is also observed in the three spectra. The absence of the $v(\mathrm{~N}-\mathrm{H})$ stretching vibration, seen at $3210 \mathrm{~cm}^{-1}$ for the proligand $\mathbf{2}$, in the spectra of both complexes $\mathbf{3}$ and $\mathbf{4}$ indicates that the ligands is bonded to palladium (II) ion in its anionic form. On the other hand, the band at 
$1630 \mathrm{~cm}^{-1}$ associated with the stretching frequency of the imine $\mathrm{C}=\mathrm{N}$ bond in proligand 2 shifted to lower wavenumbers $\left(1625 \mathrm{~cm}^{-1}\right)$ in the neutral species 3 and to $1650 \mathrm{~cm}^{-1}$ in the cationic unit of 4 , which is indicative of imine nitrogen coordination to $\mathrm{Pd}(\mathrm{II})$ center in both complexes. A very slight red shift of the band assigned to the $v(\mathrm{C}=\mathrm{O})$ of the carboxylic conjugated acid, 1683 $v s .1674 \mathrm{~cm}^{-1}$, is observed upon coordination of the proligand 2 to $\mathrm{Pd}(\mathrm{II})$ in $\mathbf{3}$. The formation of the ionic trimetallic complex $\mathbf{4}$ is testified by the presence of very strong and medium absorption bands at 844 and $558 \mathrm{~cm}^{-1}$, respectively, due to the $\mathrm{PF}_{6}{ }^{-}$counteranion. ${ }^{42,43}$

The ${ }^{1} \mathrm{H}$ NMR spectra of the proligand $\mathbf{2}$ and of its derivatized complexes $\mathbf{3}$ and $\mathbf{4}$ displayed the expected resonance patterns consistent with the proposed structures (see Experimental section for full assignments and Figs. S2-S4, ESI ${ }^{\dagger}$ ). The presence of the azomethine proton resonance appearing at $\delta_{\mathrm{H}} 8.62,8.24$ and 8.27, respectively, indicates the assembly of the quadridentate Schiff base framework. The $0.35 \mathrm{ppm}$ upfield shift of the $\mathrm{N}=\mathrm{CH}$ proton in both complexes 3 and $\mathbf{4}$ supports the coordination of the nitrogen atom to the $\operatorname{Pd}(\mathrm{II})$ metal center. The singlet observed in the $\delta_{\mathrm{H}} 5.35-5.40$ range is due to the pseudo-aromatic methine proton. The 4-hydroxyphenyl substituent is characterized by two doublets around $\delta_{\mathrm{H}}$ 7.0 and the hydroxo proton broad singlet at $\delta_{\mathrm{H}} 9.85$. The spectrum of 2 showed two deshielded resonances at $\delta_{\mathrm{H}} 10.79(\mathrm{t})$ and $13.13(\mathrm{br} \mathrm{s})$ assigned to the amino and hydroxo protons involved in hydrogen bonding with the carbonyl oxygen and the azomethine nitrogen, respectively. As expected upon complexation, those two resonances vanished in the spectra of 3 and 4 . The asymmetry of the three compounds is clearly reflected by the resonance patterns, in the $\delta_{\mathrm{H}} 3.30$ 3.85 region, of the protons of the ethylene bridge. In $\mathbf{2}$ and $\mathbf{3}$, the $\mathrm{CH}_{2}$ groups gives rise to two sets of signals, while for the trimetallic species $\mathbf{4}$ the magnetic inequivalency of the four protons is highlighted by two sets of two multiplets (Fig. S4, ESI ${ }^{\dagger}$ ). Similarly, the protons of the free and substituted cyclopentadienyl rings of the ferrocenyl moiety in proligand $\mathbf{2}$ and complex $\mathbf{3}$ showed up as a sharp singlet and two triplets at about $\delta_{\mathrm{H}} 4.1,4.3$ and 4.7, respectively (Figs. S2 and S3, ESI ${ }^{\dagger}$ ), whereas for 4 they resonated as singlet and two sets of two multiplets (Fig. S4, $\mathrm{ESI}^{\dagger}$ ). This splitting is presumably due to restricted rotation of the ferrocenyl moiety about the $\mathrm{C}_{\mathrm{ipso}}-\mathrm{C}$ resulting from coordination of the sterically demanding $\mathrm{Cp}^{*} \mathrm{Ru}^{+}$unit to the salicylide ne ring. Such a feature has previously been reported for other members of this family of ionic heterotrimetallic unsymmetrical Schiff base complexes. ${ }^{37 a, 42,43,46}$ A second outcome of the complexation of the salicylidene ring to the cationic arenophile $\mathrm{Cp}^{*} \mathrm{Ru}^{+}$is an upfield shift of the aromatic proton resonances by almost $1.5 \mathrm{ppm}$. This is explained by charge transfer between the arene and metal that results in a net reduction in $\mathrm{C}-\mathrm{C}$ bond order. ${ }^{47}$ 
Furthermore, the ${ }^{13} \mathrm{C}$ NMR spectra of 2-4 (Figs. S5-S7, ESI ${ }^{\dagger}$ ) fully reproduce the features observed in ${ }^{1} \mathrm{H}$ NMR and support the interpretation outlined above, clearly demonstrating the unsymmetrical nature of the three compounds. For instance, the two resonances at $\delta_{\mathrm{C}} 68.03\left(\mathrm{C}_{\alpha}\right)$ and $69.78\left(\mathrm{C}_{\beta}\right)$ due to the substituted cyclopentadienyl ring carbons observed in the spectrum of complex 3 , are splitted into four signals at $\delta_{\mathrm{C}} 67.60\left(\mathrm{C}_{\alpha}\right), 68.59$ $\left(\mathrm{C}_{\alpha}{ }^{\prime}\right), 69.95\left(\mathrm{C}_{\beta}\right)$ and $70.02\left(\mathrm{C}_{\beta}\right)$ for the ionic trimetallic counterpart 4 . One can also mention an upfield resonance shift of about $40 \mathrm{ppm}$ (except C-2, $24 \mathrm{ppm}$ ) of the salicylidene carbon atoms on passing from 3 to 4 . As well, the carbonyl carbon is upfield shifted by 15 ppm upon coordination to the central $\mathrm{Pd}(\mathrm{II})$ metal ion.

\section{Description of the X-ray crystal structures}

Crystals of the neutral bimetallic complex $3 \cdot \mathrm{H}_{2} \mathrm{O}$ and of the ionic trimetallic species 4 , suitable for X-ray crystallography, were grown by slow diffusion of diethyl ether into a solution of the respective complex in dimethylformamide/methanol mixture. Perspective views of the two asymmetric Schiff base complexes $\mathbf{3} \cdot \mathrm{H}_{2} \mathrm{O}$ and $\mathbf{4}$ are shown in Fig. 1. Bond distances and angles for the first $\mathrm{Pd}(\mathrm{II})$ coordination sphere are gathered in Table 1, and selected bond distances and angles for the Schiff base ligand in $\mathbf{3} \cdot \mathrm{H}_{2} \mathrm{O}$ and $\mathbf{4}$ are listed in Table S1 (see ESI ${ }^{\dagger}$ ). Complex $3 \cdot \mathrm{H}_{2} \mathrm{O}$ crystallizes as the hydrated compound in the triclinic centrosymmetric space group P-1, while the ionic complex $\mathbf{4}$ crystallizes as a cationic entity associated with a hexafluorophosphate anion, in the monoclinic centrosymmetric space group $\mathrm{P} 21 / \mathrm{n}$. The asymmetric unit of each complex contains one molecule. Each compound consists of a common ferrocenyl unit linked to a $\mathrm{Pd}(\mathrm{II})$-centered $\mathrm{N}_{2} \mathrm{O}_{2}$ unsymmetrical macroacyclic Schiff base framework. The main difference between these two complexes is the electron withdrawing substituent borne by the salicylidene ring. That is the carboxylic $\mathrm{CO}_{2} \mathrm{H}$ functionality in $\mathbf{3} \cdot \mathrm{H}_{2} \mathrm{O}$ and the cationic organometallic fragment $\mathrm{Cp}^{*} \mathrm{Ru}^{+}$in 4 . In this latter species, the organometallic moieties $\mathrm{CpFe}$ and $\mathrm{Cp}^{*} \mathrm{Ru}+$ are located on opposite face of the dinucleating inorganic ligand. This anti-conformation was also reported for the parent nickel derivative. ${ }^{42}$ The ferrocenyl moieties were unexceptional, featuring in both cases a typical linear $\eta^{5}-\mathrm{Fe}-\eta^{5}$ sandwich structure in accordance with a Fe(II) oxidation state and Table S2 summarises selected metrical parameters $\left(\mathrm{ESI}^{\dagger}\right)$. The cyclopentadienyl rings are parallel and eclipsed. 


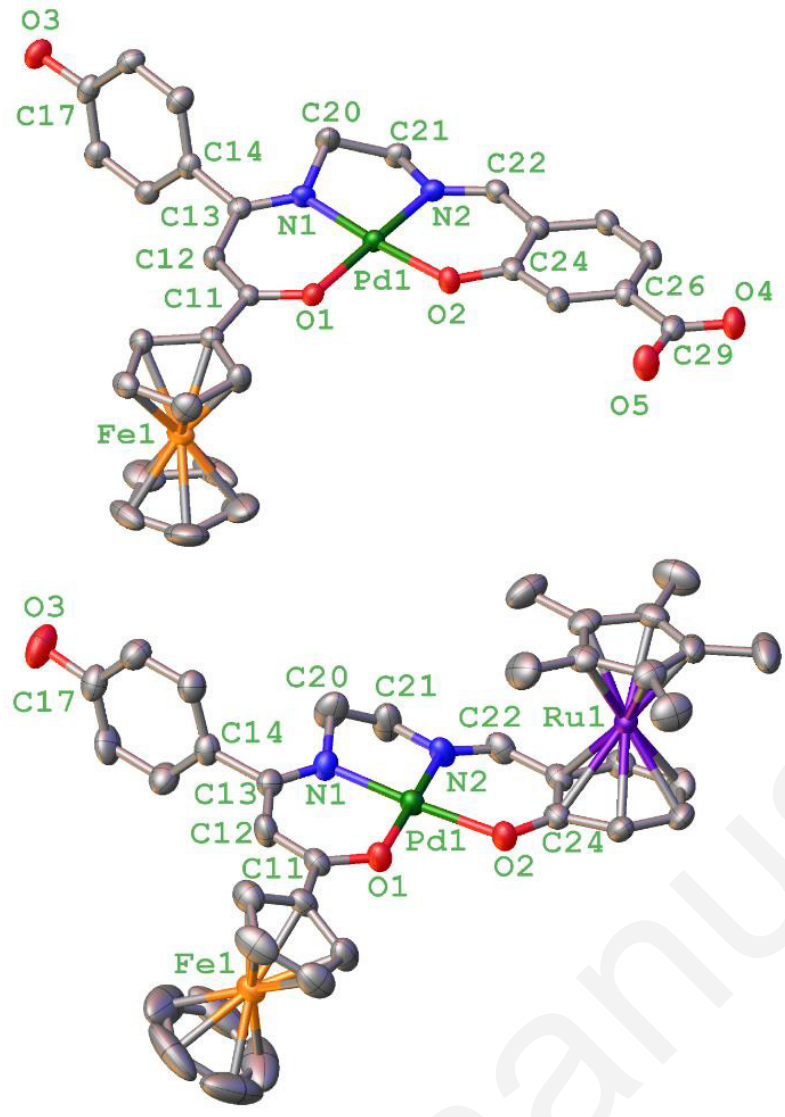

Fig. 1 Molecular structures of bimetallic complex $3 \cdot \mathrm{H}_{2} \mathrm{O}$ (top) and of cationic part of trimetall ic complexes 4 (bottom), with labelling scheme for selected atoms. Hydrogen atoms, water molecule for $3 \cdot \mathrm{H}_{2} \mathrm{O}$ and $\mathrm{PF}_{6}{ }^{-}$counter anion for $\mathbf{4}$ have been omitted for clarity. Thermal ellipsoids are drawn at the $50 \%$ probability level.

Table 1 Selected bond distances $(\AA)$ and angles $\left(^{\circ}\right)$ for the first $\operatorname{Pd}(\mathrm{II})$ coordination sphere of compounds $3 \cdot \mathrm{H}_{2} \mathrm{O}$ and 4 . 


\begin{tabular}{lcc}
\hline & $3 \cdot \mathrm{H}_{2} \mathrm{O}$ & $\mathbf{4}$ \\
\hline & Bond distances \\
\hline $\mathrm{Pd}(1)-\mathrm{O}(1)$ & $2.000(2)$ & $1.996(3)$ \\
$\mathrm{Pd}(1)-\mathrm{O}(2)$ & $2.008(2)$ & $2.031(3)$ \\
$\mathrm{Pd}(1)-\mathrm{N}(1)$ & $1.958(3)$ & $1.956(4)$ \\
$\mathrm{Pd}(1)-\mathrm{N}(2)$ & $1.957(3)$ & $1.963(4)$ \\
\hline & Bond angles & \\
\hline $\mathrm{O}(1)-\mathrm{Pd}(1)-\mathrm{N}(2)$ & $177.58(10)$ & $177.08(17)$ \\
$\mathrm{O}(2)-\mathrm{Pd}(1)-\mathrm{N}(1)$ & $175.97(10)$ & $176.75(16)$ \\
$\mathrm{O}(1)-\mathrm{Pd}(1)-\mathrm{N}(1)$ & $95.01(10)$ & $94.96(16)$ \\
$\mathrm{O}(1)-\mathrm{Pd}(1)-\mathrm{O}(2)$ & $87.61(9)$ & $87.62(14)$ \\
$\mathrm{O}(2)-\mathrm{Pd}(1)-\mathrm{N}(2)$ & $93.31(10)$ & $93.51(16)$ \\
$\mathrm{N}(1)-\mathrm{Pd}(1)-\mathrm{N}(2)$ & $84.18(11)$ & $84.00(18)$ \\
\hline
\end{tabular}

complexes, the $\operatorname{Pd}(\mathrm{II})$ ion

In both $\mathrm{N}(1)-\mathrm{Pd}(1)-\mathrm{N}(2)$

tetracoordinated, bonded to the four $\mathrm{N}_{2} \mathrm{O}_{2}$ donor atoms set of the tetradentate dianionic Schiff base ligand (Fig. 1) forming one five- and two six-membered chelate rings with N-Pd-N and $\mathrm{O}-\mathrm{Pd}-\mathrm{N}$ bite angles of $\sim 84^{\circ}$ and $\sim 95^{\circ}$, respectively (Table 1 ). In both cases, the nitrogen and oxygen atoms occupy mutually trans dispositions with diagonal $\mathrm{O}-\mathrm{Pd}-\mathrm{N}$ angles close to the idealized value of $180^{\circ}$ (Table 1). Thus, the geometry around $\mathrm{Pd}(\mathrm{II})$ atom reveals a quasi-perfect square planar coordination environment with $\tau_{4}$ index values of 0.042 for $3 \cdot \mathrm{H}_{2} \mathrm{O}$ and 0.044 for 4. ${ }^{48}$ The bond lengths associated with the palladium atom range between 1.956(4) and 2.031(3) $\AA$ (Table 1), and are comparable to the $\mathrm{Pd}-\mathrm{O}$ and $\mathrm{Pd}-\mathrm{N}$ distances reported in the literature. ${ }^{49,50}$

On the other hand, the two six-membered heterometallacycles are planar with O-C, C$\mathrm{C}$ and $\mathrm{C}-\mathrm{N}$ bond lengths ranging between reported values for single and double bonds (see Table S1, ESI ${ }^{\dagger} .{ }^{51}$ These two subunits are held together by the five-membered diazametallacycle that assumes an envelope conformation with the flap carbon deviating from the mean $\left[\mathrm{NPdNC}\right.$ ] plane by $0.417(7) \AA$ in $\mathbf{3} \cdot \mathrm{H}_{2} \mathrm{O}$ and $0.414(12) \AA$ in $\mathbf{4}$. In $\mathbf{3} \cdot \mathrm{H}_{2} \mathrm{O}$, the planes of the phenol and substituted cyclopentadienyl ring made dihedral angles of $70.5^{\circ}$ and $6.8^{\circ}$, respectively, with the mean plane of the heterometallacycle to which they are attached. In the trimetallic species 4 , the values of these angles increase to $82.5^{\circ}$ and $24.6^{\circ}$, respectively, presumably to accommodate the steric demand brought about by the bulky arenophile $\mathrm{Cp} * \mathrm{Ru}^{+}$. 
Similar torsion of these substituents have previously been measured in this family of Schiff base complexes. ${ }^{32,37 b, 42}$

Additionally, in $3 \cdot \mathrm{H}_{2} \mathrm{O}$ the carboxylic group is co-planar with the plane of the salicylidene ring (dihedral angle $=0.34(2)^{\circ}$ ). This arrangement favors the electronic delocalization and communication between the donor and acceptor groups through the $\mathrm{Pd}(\mathrm{II}) / \mathrm{Schiff}$ base skeleton. In $\mathbf{4}$, the organometallic acceptor moiety is $\eta^{6}$-coordinated to the salicylidene ring forming a mixed sandwich with parallel rings, the angle formed between the ligand centroids and the focal metal atom $\left(177.6^{\circ}\right)$ deviates barely from linearity. The ring centroid-Ru distances are of $1.818 \AA$ and $1.734 \AA$ for ring $=\mathrm{Cp}^{*}$ and salicylidene, respectively.

Lastly, the packing of the bimetallic complex $3 \cdot \mathrm{H}_{2} \mathrm{O}$ showed that the structure is stabilized by a network of intermolecular hydrogen bonds (Fig. 2 and Table S3, ESI'). Specifically, hydrogen-bonding interactions occur between: (i) the phenolic hydrogen (O3-H3) and the oxygen atom of the crystallization water molecule $(\mathrm{Ow}-\mathrm{Hw})$ with an $\mathrm{O} \cdots \mathrm{O}$ separation of 2.713(4) $\AA$, (ii) the hydrogens of the same water molecule (Ow-Hw) and the phenoxo oxygen (O2) of the Schiff base ligand $(\mathrm{O} \cdots \mathrm{O}=2.669(3) \AA$, and (iii) the hydrogen of the carboxylic acid (O5-H5) and the carbonyl $-\mathrm{C}(=\mathrm{O}) \mathrm{OH}$ oxygen $(\mathrm{O} 4,-\mathrm{x},-\mathrm{y},-\mathrm{z})$ of the neighboring molecule, showing a short $\mathrm{O} \cdots \mathrm{O}$ separation of 2.594(2) $\AA$. An intermolecular hydrogen bonding interaction, characterized by a $\mathrm{O} \cdots \mathrm{O}$ separation of 2.801(6) $\AA$, is also observed in $\mathbf{4}$ between the phenolic hydrogen (O3-H3) and the phenoxo oxygen $(\mathrm{O} 2, \mathrm{x}-1 / 2,-\mathrm{y}-1 / 2, \mathrm{z}-1 / 2)$ of the tetradentate chelate of a neighboring molecule, leading to the formation of infinite chains (Fig. S8 and Table S3, ESI ${ }^{\dagger}$.

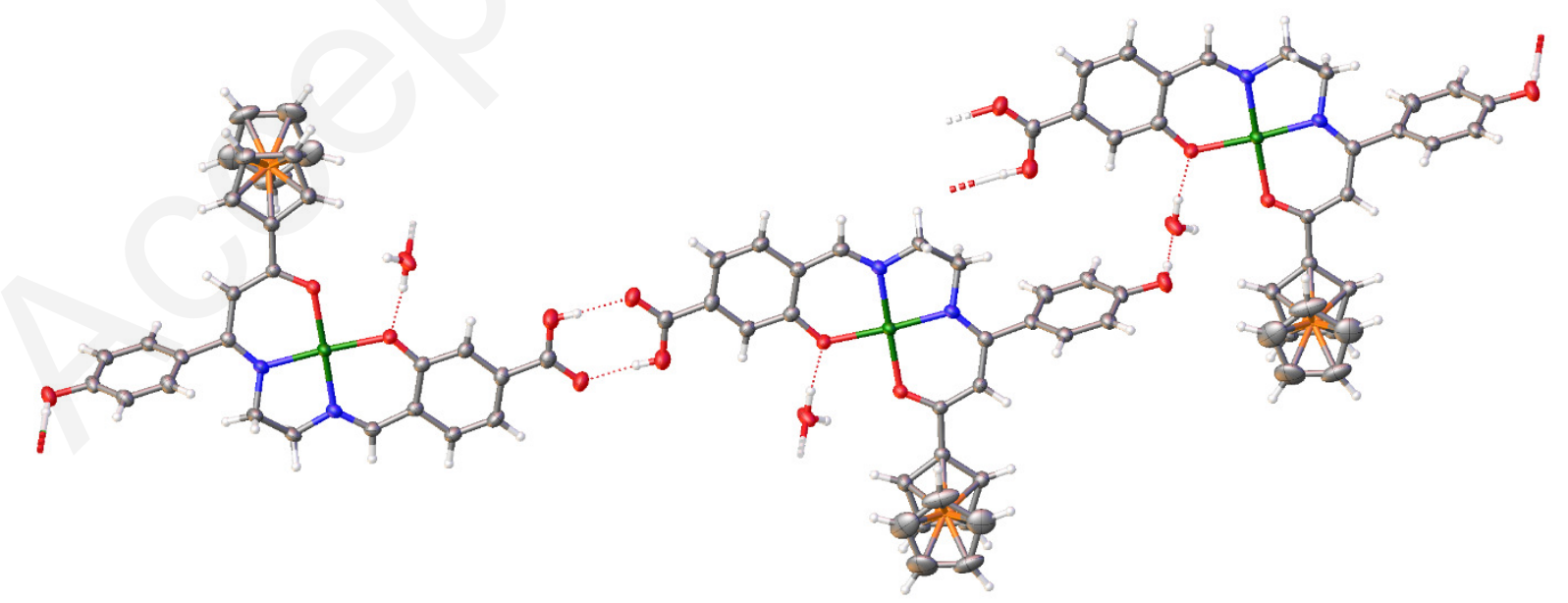

Fig. 2 Packing diagram of the bimetallic complex $3 \cdot \mathrm{H}_{2} \mathrm{O}$ showing the molecular arrangement within the crystal lattice through intermolecular hydrogen bonds. 


\section{Thermal analysis}

The thermal stability of the two Pd(II) complexes $\mathbf{3}$ and $\mathbf{4}$ were evaluated by Thermo Gravimetric Analysis (TGA), carried out under aerobic conditions with an air flow of $100 \mathrm{~mL}$ $\min ^{-1}$ at a heating rate of $10{ }^{\circ} \mathrm{C} \mathrm{min}^{-1}$. The TGA was performed in order to estimate the thermal degradations intervals (Fig. 3). The two compounds exhibited mass loss at low temperature, about $100{ }^{\circ} \mathrm{C}$ for $\mathbf{3}$ and somewhat higher for $\mathbf{4}$, due to the presence of water or other solvents. This mass loss is rather weak in both compounds, with values of $8 \%$ and $3 \%$, respectively (Table 2). The initial decomposition temperature is $216^{\circ} \mathrm{C}$ for 3 and at $270{ }^{\circ} \mathrm{C}$ for 4 . This latter higher temperature could be related to a greater rigidity and ionic nature of the trimetallic complex 4 thanks to the presence of the cationic organometallic $\mathrm{Cp}^{*} \mathrm{Ru}^{+}$arenophile. Interestingly, this observed good thermal stability should allow the incorporation of the investigated chromophores into polymers matrix with high glass transition temperature, an important prerequisite for potential future practical uses. ${ }^{52}$

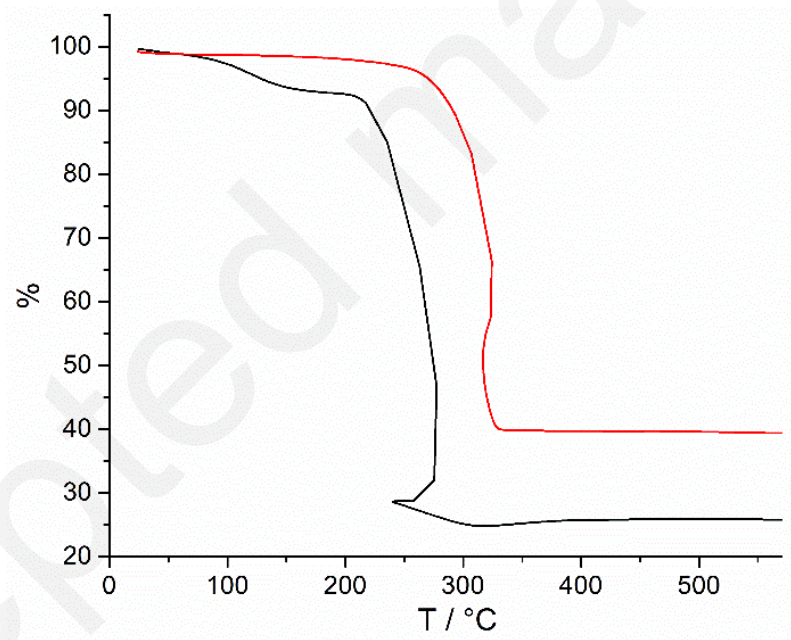

Fig. 3 TGA curves of complexes 3 (black curve) and 4 (red curve) between 25 and $570{ }^{\circ} \mathrm{C}$. The irregularities observed in the TGA curves of 3 and $\mathbf{4}$ (between $241-278{ }^{\circ} \mathrm{C}$ and $325-331{ }^{\circ} \mathrm{C}$, respectively) are due to the presence of air that generates an abrupt decomposition in these temperature ranges.

Table 2 Decomposition temperature ranges of $\mathrm{Pd}(\mathrm{II})$ complexes 3 and $\mathbf{4}$.

\begin{tabular}{ccccc}
\hline Compd. & $\begin{array}{c}\text { Moisture loss } \\
\left({ }^{\circ} \mathrm{C}\right)\end{array}$ & $\begin{array}{c}\text { Mass loss } \\
(\%)\end{array}$ & $\begin{array}{c}\text { Thermal degradation } \\
\left({ }^{\circ} \mathrm{C}\right)\end{array}$ & $\begin{array}{c}\text { Mass loss } \\
(\%)\end{array}$ \\
\hline $\mathbf{3}$ & $25-216$ & 8 & $216-315$ & 71 \\
$\mathbf{4}$ & $25-270$ & 3 & $270-349$ & 59 \\
\hline
\end{tabular}




\section{Electrochemical properties}

The electrochemical features of the Pd(II) Schiff base complexes $\mathbf{3}$ and $\mathbf{4}$ were investigated using cyclic voltammetry (CV) in DMF containing $0.1 \mathrm{M} n-\mathrm{Bu}_{4} \mathrm{~N}^{+} \mathrm{PF}_{6}^{-}$as supporting electrolyte. The CV measurements were carried out at room temperature in the +0.3 to $+1.0 \mathrm{~V} v s . \mathrm{Ag} / \mathrm{AgCl}$ potential range with scan rate of $100 \mathrm{mV} \cdot \mathrm{s}^{-1}$ (Fig. S9, ESI'). Each of the compounds displays one chemically reversible redox process due to the monoelectronic oxidation of the ferrocenyl moiety, with current ratio $i_{\mathrm{pa}} / i_{\mathrm{pc}}$ equal to unity. ${ }^{53}$ The redox potentials of the two compounds are anodically shifted by $180 \mathrm{mV}$ and $210 \mathrm{mV}$, respectively, with respect to free ferrocene under the same electrochemical conditions (Table 3). This increased difficulty in oxidizing the $\mathrm{Fe}(\mathrm{II})$ center is due to the electron-withdrawing nature of the side-chain $\left[\mathrm{Pd}\left(\mathrm{N}_{2} \mathrm{O}_{2}\right)\right]$ Schiff base substituent. It is worth mentioning that the magnitude of the redox potential of the ferrocenyl group has been regarded as an important factor in the study of conjugated push-pull chromophores, being related in many cases with high second-order nonlinear optical responses. ${ }^{9,54,55}$ The $E_{1 / 2}$ values of 0.58 and $0.61 \mathrm{~V}$ found for $\mathbf{3}$ and $\mathbf{4}$, respectively, corroborate our previous data obtained with a similar Pd(II) complex of a Schiff base ligand derived from condensation of $\mathbf{1}$ and 5-nitrosalicylaldehyde. ${ }^{32}$ In this latter case, the anodic shift is, however, higher $(240 \mathrm{mv})$, owing to the most powerful electron withdrawing ability of the $\mathrm{NO}_{2}$ substituent. The observed large anodic shifts clearly indicate that the $\mathrm{Pd}^{\mathrm{II}}$ ion greatly facilitates the electronic communication between the donor and acceptor ends of the molecules. It is also likely that the palladium (II) center is playing an electro-attractive effect due to its Lewis acidity. ${ }^{56}$

Table 3 Formal Electrode Potentials and Peak-to-Peak Separations for the $\mathrm{Fe}^{\mathrm{II}} / \mathrm{Fe}^{\mathrm{III}}$ Redox Processes Exhibited by complexes 3 and $4 .^{a}$

\begin{tabular}{ccc}
\hline Compd. & $E_{1 / 2}(\mathrm{~V})$ & $\Delta E_{\mathrm{p}}(\mathrm{mV})$ \\
\hline $\mathbf{3}$ & 0.58 & 76 \\
$\mathbf{4}$ & 0.61 & 82 \\
$\mathrm{Cp}_{2} \mathrm{Fe}$ & 0.40 & 98 \\
\hline
\end{tabular}

${ }^{a}$ Recorded in DMF containing $0.1 \mathrm{M}\left[n-\mathrm{Bu}_{4} \mathrm{~N}\right]\left[\mathrm{PF}_{6}\right]$ at $T=298 \mathrm{~K}$ with a sweep rate $v=100 \mathrm{mV}$ $\mathrm{s}^{-1}$, reference electrode $\mathrm{Ag} / \mathrm{AgCl}$.

\section{Electronic absorption spectroscopy}


The UV-vis absorption spectra of the asymmetric Schiff base complexes $\mathbf{3}$ and $\mathbf{4}$ were recorded in the 330-800 $\mathrm{nm}$ range in both tetrahydrofuran (THF) and dimethylsulfoxide (DMSO) solutions. Their experimental spectra are shown in Fig. 4. They are mainly composed of a broad absorption band which, upon deconvolutions with Gaussian curves, gives rise to two transitions (Table 4). The first maxima at 367 and $365 \mathrm{~nm}$, respectively, could be assigned to the $\pi-\pi^{*}$ transitions of the imine groups and aromatic rings, thus belonging to the intra ligand charge transfer (ILCT) transitions. The second maxima at 443 and $466 \mathrm{~nm}$, respectively, are presumably mixture of ligand-to-metal (LM) and metal-to-ligand (ML) charge transfer (CT) transitions. UV-vis spectra of $\mathbf{3}$ and $\mathbf{4}$ are indicative of four coordinate diamagnetic $\mathrm{Pd}(\mathrm{II})$ complexes with square planar geometry of $d^{8}$ configuration. ${ }^{49,57}$ TD-DFT calculations of square planar Pd(II) complexes containing asymmetric Schiff base ligands have shown that the transitions have mixed character of ILCT, LMCT and MLCT which is $\pi-\pi^{*}$ in nature. ${ }^{32,49,50}$ All those major features of the experimental spectra are reproduced on passing from THF to the more polar DMSO solvent. The bands exhibit either bathochromic or hypsochromic shifts (Table 4), characteristic of a dipole moment change between the ground and excited state, and indicative of a CT character. Such a solvatochromism is also characteristic of push-pull complexes and is related to their NLO properties. ${ }^{10,58,59}$
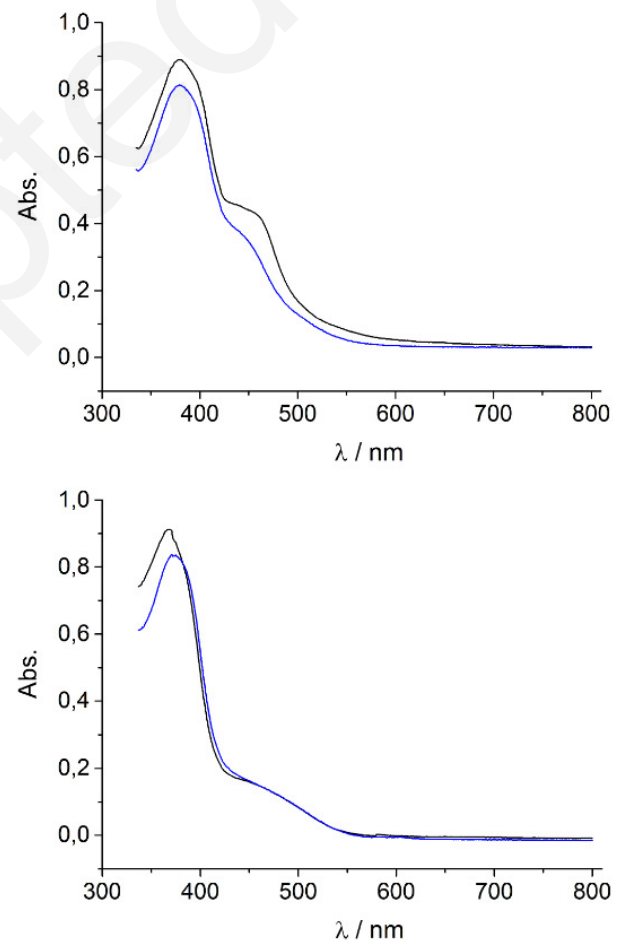
Fig. 4 UV-vis spectra of binuclear complex 3 (top) and trinuclear complex 4 (bottom) recorded in THF (black line) and DMSO (blue line) solutions.

Table 4 UV-vis absorption data for Pd(II)-containing compounds 3 and 4 .

\begin{tabular}{cccc}
\hline Compd & $\begin{array}{c}\lambda / \mathrm{nm}(\log \varepsilon) \\
(\mathrm{THF})\end{array}$ & $\begin{array}{c}\lambda / \mathrm{nm}(\log \varepsilon) \\
(\mathrm{DMSO})\end{array}$ & Solv. Shift $/ \mathrm{cm}^{-1}$ \\
\hline \multirow{3}{*}{4} & $367(3,88)$ & $374(3,44)$ & +510 \\
& $443(3,56)$ & $435(3,07)$ & -415 \\
& $365(3,96)$ & $375(3,55)$ & +731 \\
& $466(3,15)$ & $449(2,89)$ & -812 \\
\hline
\end{tabular}

\section{Quadratic Nonlinear Optical Studies}

The quadratic nonlinear responses of the neutral proligand $\mathbf{2}$ and bimetallic complex $\mathbf{3}$, and of the ionic trimetallic derivative 4 have been determined at $1.91 \mu \mathrm{m}$ incident wavelength using the Harmonic Light Scattering (HLS) technique (see Experimental for details). ${ }^{60}$ HLS measurements were carried out in DMF solutions for the three compounds. The experimental values of the multipolar first hyperpolarizability $\left(\beta_{1.91}\right)$ are gathered in Table 5.

Table 5 HLS $\beta$ values determined at $\lambda_{\text {inc }} 1.91 \mu \mathrm{m}$ for compounds $\mathbf{2 - 4}{ }^{a}$

\begin{tabular}{cc}
\hline Compd. $^{b}$ & $\beta\left(10^{-30} \mathrm{esu}\right)$ \\
\hline $\mathbf{2}$ & 160 \\
$\mathbf{3}$ & 140 \\
$\mathbf{4}$ & 130 \\
Relative experimental error on $\beta$ values is $\pm 10 \%$. \\
${ }^{b} 10^{-2} \mathrm{M}$ solution in DMF.
\end{tabular}

The results are a little bit surprising. Firstly, contrary to what we have always observed, ${ }^{32,37 \mathrm{a}, \mathrm{b}}$ the $\beta_{1.91}$ value of the asymmetric metalloligand precursor $\mathbf{2}$ is slightly greater than that of its corresponding complex $\mathbf{3}$ despite the formation of a geometrically constrained planar structure around the $\mathrm{Pd}(\mathrm{II})$ center which should increase the conjugation and, hence, the nonlinear efficiency. Secondly, based on the electrochemical data (see above), we could expect a $\beta_{1.91}$ value for 3 close to that determined for the related $\mathrm{Pd}(\mathrm{II})$ chromophore bearing a $5-\mathrm{NO}_{2}$ substituent. Instead, it is almost seven-fold lower than the $\beta_{1.91}$ value $\left(960 \times 10^{-30} \mathrm{esu}\right)$ determined for the 5-nitrosubstituted counterpart. ${ }^{32}$ This dramatic drop has probably two origins. First, the nitro group is a much stronger electron-attracting group than $\mathrm{COOH}$, resulting 
in much higher $\beta$ values than for a carboxylic acid substituent. A second possibility (not exclusive of the first one) could arise from hydrogen bonding induced dimerization in solution through the $-\mathrm{CO}_{2} \mathrm{H}$ functionality, as observed in the solid state (see above), forming a [D- $\pi$ $\mathrm{A} \cdots \mathrm{A}-\pi$-D]-type structure. In such a structure, steric constraints could also favor this decrease of $\beta$ by generating a substantial twisting of the ferrocenyl moieties that may be a barrier to efficient ILCT. On the other hand, the $\beta_{1.91}$ value obtained for 4 is identical, within the $10 \%$ measurement uncertainty, to the $\beta_{1.91}$ values $\left(120 \times 10^{-30} \mathrm{esu}\right)$ found previously under the same experimental conditions for the nickel(II) counterpart, despite a greater anodic shift $(210 \mathrm{mv}$ vs. $90 \mathrm{mv}$ ) of the $\mathrm{Fe}(\mathrm{II}) / \mathrm{Fe}(\mathrm{III})$ redox couple of the ferrocenyl moiety. ${ }^{42}$

\section{Conclusion}

To sum up, we have successfully synthesized and fully characterized two new secondorder NLO active palladium(II) complexes, $\mathbf{3}$ and $\mathbf{4}$, of metallocenyl-containing unsymmetrically-substituted Schiff bases ligands. They were both prepared via a threecomponent one-pot template reaction involving the 4-hydroxyphenyl substituted ferrocenylcontaining half unit $\mathbf{1}$, palladium acetate and the appropriate salicylaldehyde derivative. Complex 3 is a neutral bimetallic species having a $\mathrm{CO}_{2} \mathrm{H}$-functionalized salicylidene ring while 4 is an ionic trimetallic compound in which the salicylidene ring is $\eta^{6}$-coordinated to the cationic electron withdrawing arenophile $\mathrm{Cp}^{*} \mathrm{Ru}^{+}$. Their thermal, electrochemical, linear, and second-order nonlinear optical properties have been thoroughly investigated. Single crystal Xray structures of both compounds reveal that the central four-coordinate $\operatorname{Pd}(\mathrm{II})$ ion sits in a square planar geometry with partial delocalization of bonding electron density throughout the $\left[\mathrm{Pd}\left(\mathrm{N}_{2} \mathrm{O}_{2}\right)\right]$ Schiff base framework, and that in the ionic organometallic-inorganic hybrid derivative 4 the two metallocenyl units adopts the anti-configuration about the dinucleating ligand. The electrochemical analysis nicely illustrates through the strong anodic potentials of the $\mathrm{Fe}(\mathrm{II}) / \mathrm{Fe}$ (III) redox couple that the electronic communication between the electronreleasing and withdrawing groups is greatly facilitated in the two investigated push-pull D- $\pi$-A chromophores. They both exhibit second-order NLO responses, and even though the quadratic hyperpolarizability $\beta$ values measured via the HLS technique at $1.91 \mu \mathrm{m}$ in DMF are rather good, it appears that correlating redox potentials and NLO responses must be done cautiously. Nevertheless, for expending the field of applications of NLO-active Schiff base compounds for the further elaboration of NLO materials, $-\mathrm{OH}$ and $-\mathrm{CO}_{2} \mathrm{H}$ linkers are attractive sites for anchoring the complexes onto various supports. 


\section{Experimental Section}

\section{Materials and physical techniques}

All manipulations were carried out under a dinitrogen atmosphere using standard Schlenk techniques. The solvents were dried and distilled according to standard procedures. ${ }^{61}$ Palladium(II) acetate and 4-formyl-3-hydroxybenzoic acid were purchased from Aldrich and used without further purification. The organometallic ONN-tridentate "half unit" Fc$\mathrm{C}(=\mathrm{O}) \mathrm{CH}=\mathrm{C}\left(4-\mathrm{C}_{6} \mathrm{H}_{4} \mathrm{OH}\right) \mathrm{N}(\mathrm{H}) \mathrm{CH}_{2} \mathrm{CH}_{2} \mathrm{NH}_{2}(\mathbf{1})^{41}$ and the salicylaldehyde complex $\left[\mathrm{Cp} * \mathrm{Ru}\left(\eta^{6}-\right.\right.$ 2-OH- $\left.\left.\mathrm{C}_{6} \mathrm{H}_{4} \mathrm{CHO}\right)\right] \mathrm{PF}_{6}{ }^{45}$ were synthesized following the established literature procedures. Solid-state FT-IR spectra were recorded on a Perkin-Elmer Model 1600 FT-IR spectrophotometer with $\mathrm{KBr}$ disks in the 4000 to $450 \mathrm{~cm}^{-1}$ range. Electronic spectra were obtained with a Thermo Scientific Model Helios Omega 76006 v8.0 spectrophotometer. NMR spectra were obtained at $298 \mathrm{~K}$ on a Bruker Avance III 400 or Avance 500 spectrometer. All NMR spectra are reported in parts per million (ppm, $\delta$ ) relative to tetramethylsilane $\left(\mathrm{Me}_{4} \mathrm{Si}\right)$, with the residual solvent proton and carbon resonances used as internal standards. Coupling constants $(J)$ are reported in Hertz $(\mathrm{Hz})$, and integrations are reported as number of protons. The following abbreviations are used to describe peak patterns: $\mathrm{s}=$ singlet, $\mathrm{d}=$ doublet, $\mathrm{t}=$ triplet, $\mathrm{m}=$ multiplet, br $=$ broad. ${ }^{1} \mathrm{H}$ and ${ }^{13} \mathrm{C} \mathrm{NMR}$ chemical shift assignments are supported by data obtained from ${ }^{1} \mathrm{H}-{ }^{1} \mathrm{H}$ COSY, ${ }^{1} \mathrm{H}-{ }^{13} \mathrm{C} \mathrm{HMQC}$, and ${ }^{1} \mathrm{H}-{ }^{13} \mathrm{C}$ HMBC NMR experiments. Elemental analyses were conducted on a Thermo-Finnigan Flash EA 1112 CHNS/O analyzer by the Microanalytical Service of the CRMPO at the université de Rennes 1 (France). Cyclic voltammetry (CV) measurements were performed using a $\mathrm{CH}$ Instruments model Ch604E potentiostat (Ch Instruments Inc., Austin, TX, USA), using a standard three-electrode setup with a vitreous carbon working electrode, platinum wire auxiliary electrode, and $\mathrm{Ag} / \mathrm{AgCl}$ as the reference electrode. Dimethylformamide (DMF) solutions were $2.0 \mathrm{mM}$ in the compound under study and $0.1 \mathrm{M} n-\mathrm{Bu}_{4} \mathrm{~N}^{+} \mathrm{PF}_{6}{ }^{-}$as supporting electrolyte, with voltage scan rate $=100 \mathrm{mV}$ $\mathrm{s}^{-1} \cdot E_{1 / 2}$ is defined as equal to $\left(E_{\mathrm{pa}}+E_{\mathrm{pc}}\right) / 2$, where $E_{\mathrm{pa}}$ and $E_{\mathrm{pc}}$ are the anodic and cathodic peak potentials, respectively. The ferrocene/ferricenium redox couple $\left(\mathrm{Cp}_{2} \mathrm{Fe} / \mathrm{Cp}_{2} \mathrm{Fe}^{+}\right)$was used as internal reference for the potential measurements. The TGA analysis was carried out with a Thermal Analysis model Q600 SDT instrument in the range $25-575^{\circ} \mathrm{C}$ with an air flow of 100 $\mathrm{mL} \min ^{-1}$ at a heating rate of $10{ }^{\circ} \mathrm{C} \mathrm{min}^{-1}$. 
To a Schlenk tube containing a stirred solution of half unit $\mathbf{1}(100 \mathrm{mg}, 0.26 \mathrm{mmol})$ in ethanol $(50 \mathrm{~mL})$ was added dropwise 4-formyl-3-hydroxybenzoic acid (43 $\mathrm{mg}, 0.26 \mathrm{mmol})$ in ethanol $(10 \mathrm{~mL})$. After completion of addition, the reaction medium was refluxed for $2 \mathrm{~h}$. Upon cooling to room temperature, a diethyl ether/hexane 4:1 mixture $(20 \mathrm{~mL})$ was added and the Schlenk tube was stored at $-15^{\circ} \mathrm{C}$ for $24 \mathrm{~h}$. The red precipitate that formed was collected by filtration, washed with diethyl ether and pentane $(2 \times 3 \mathrm{~mL})$, and dried under vacuum. Yield: $116 \mathrm{mg}, 83 \%$. Elemental analysis (\%)Calculated for $\mathrm{C}_{29} \mathrm{H}_{26} \mathrm{FeN}_{2} \mathrm{O}_{5} \cdot 0.5 \mathrm{H}_{2} \mathrm{O}\left(547.39 \mathrm{~g} \mathrm{~mol}^{-1}\right)$ : C, 63.63; H, 5.08; N, 5.12. Found: C, 63.20; H, 4.99; N, 4.94. IR $\left(\mathrm{KBr}, \mathrm{cm}^{-1}\right): 3360(\mathrm{~m}) v(\mathrm{O}-\mathrm{H})$, 3210(w) $v(\mathrm{~N}-\mathrm{H}), 3098(\mathrm{w}), 3070(\mathrm{w}) v(\mathrm{C}-\mathrm{H}$ arom), 2971(w), 2920(w), 2892(m) $v(\mathrm{C}-\mathrm{H}$ aliph), $1683(\mathrm{~m}) v(\mathrm{C}=\mathrm{O}), 1630(\mathrm{~m}), 1612$ (s) 1597 (s) $v(\mathrm{C}=\mathrm{O}), v(\mathrm{C}=\mathrm{C})$ and/or $v(\mathrm{C} \cdots \mathrm{N}), 1270(\mathrm{~s})$ $v(\mathrm{C}-\mathrm{O}) .{ }^{1} \mathrm{H}$ NMR $\left(400 \mathrm{MHz},\left(\mathrm{CD}_{3}\right)_{2} \mathrm{SO}\right): \delta_{\mathrm{H}} 3.52\left(\mathrm{q},{ }^{3} J_{\mathrm{H}, \mathrm{H}}=5.4 \mathrm{~Hz}, 2 \mathrm{H}, \mathrm{NCH}_{2}\right), 3.74\left(\mathrm{t},{ }^{3} J_{\mathrm{H}, \mathrm{H}}\right.$ $\left.=5.4 \mathrm{~Hz}, 2 \mathrm{H}, \mathrm{CH}_{2} \mathrm{~N}\right), 4.10\left(\mathrm{~s}, 5 \mathrm{H}, \mathrm{C}_{5} \mathrm{H}_{5}\right), 4.37\left(\mathrm{t},{ }^{3} J_{\mathrm{H}, \mathrm{H}}=1.8 \mathrm{~Hz}, 2 \mathrm{H}, \mathrm{H}_{3} \mathrm{C}_{5} \mathrm{H}_{4}\right), 4.68\left(\mathrm{t},{ }^{3} J_{\mathrm{H}, \mathrm{H}}\right.$ $\left.=1.8 \mathrm{~Hz}, 2 \mathrm{H}, \mathrm{H}_{\alpha} \mathrm{C}_{5} \mathrm{H}_{4}\right), 5.36(\mathrm{~s}, 1 \mathrm{H}, \mathrm{CH}=\mathrm{C}), 6.86\left(\mathrm{~d},{ }^{3} J_{\mathrm{H}, \mathrm{H}}=8.5 \mathrm{~Hz}, 2 \mathrm{H}, \mathrm{C}_{6} \mathrm{H}_{4}\right), 7.29\left(\mathrm{~d},{ }^{3} J_{\mathrm{H}, \mathrm{H}}\right.$ $\left.=8.5 \mathrm{~Hz}, 2 \mathrm{H}, \mathrm{C}_{6} \mathrm{H}_{4}\right), 7.40\left(\mathrm{~d},{ }^{4} J_{\mathrm{H}, \mathrm{H}}=1.4 \mathrm{~Hz}, 1 \mathrm{H}, \mathrm{H}-3\right), 7.43\left(\mathrm{dd},{ }^{3} J_{\mathrm{H}, \mathrm{H}}=8.0 \mathrm{~Hz},{ }^{4} J_{\mathrm{H}, \mathrm{H}}=1.4\right.$ $\mathrm{Hz}, 1 \mathrm{H}, \mathrm{H}-5), 7.54\left(\mathrm{~d},{ }^{3} J_{\mathrm{H}, \mathrm{H}}=8.0 \mathrm{~Hz}, 1 \mathrm{H}, \mathrm{H}-6\right), 8.62(\mathrm{~s}, 1 \mathrm{H}, \mathrm{N}=\mathrm{CH}), 10.79\left(\mathrm{t},{ }^{3} J_{\mathrm{H}, \mathrm{H}}=6.0 \mathrm{~Hz}\right.$, $1 \mathrm{H}, \mathrm{N}-\mathrm{H}), 13.13$ (br s, OH); $\mathrm{CO}_{2} \mathrm{H}$ proton not observed. ${ }^{13} \mathrm{C}\left\{{ }^{1} \mathrm{H}\right\} \mathrm{NMR}\left(100 \mathrm{MHz},\left(\mathrm{CD}_{3}\right)_{2} \mathrm{SO}\right)$ : $\delta_{\mathrm{C}} 44.80\left(\mathrm{NCH}_{2}\right), 59.23\left(\mathrm{CH}_{2} \mathrm{~N}\right), 68.10\left(\mathrm{C}_{\alpha} \mathrm{C}_{5} \mathrm{H}_{4}\right), 69.36\left(\mathrm{C}_{5} \mathrm{H}_{5}\right), 70.34\left(\mathrm{C}_{\beta} \mathrm{C}_{5} \mathrm{H}_{4}\right), 82.79\left(\mathrm{C}_{\text {ipso }}\right.$ $\left.\mathrm{C}_{5} \mathrm{H}_{4}\right), 94.26(\mathrm{CH}=\mathrm{C}), 115.24\left(\mathrm{C}_{6} \mathrm{H}_{4}\right), 117.06$ (C-3), 119.10 (C-5), 121.78 (C-1), $125.75 \mathrm{C}_{\text {ipso }}$ $\left.\mathrm{C}_{6} \mathrm{H}_{4}\right), 129.39\left(\mathrm{C}_{6} \mathrm{H}_{4}\right), 131.59$ (C-6), 134.13 (C-4), 158.62 ( $\left.\mathrm{C}_{\mathrm{ipso}} \mathrm{C}_{6} \mathrm{H}_{4} \mathrm{OH}\right), 159.96$ (C-2), $164.05(\mathrm{CH}=C), 166.49(\mathrm{~N}=\mathrm{CH}), 166.68\left(\mathrm{CO}_{2} \mathrm{H}\right), 190.90(\mathrm{C}=\mathrm{O})$.

\section{Synthes is of $\left[\mathrm{Pd}\left\{\mathrm{Fc}-\mathrm{C}(=\mathrm{O}) \mathrm{CH}=\mathrm{C}\left(4-\mathrm{C}_{6} \mathrm{H}_{4} \mathrm{OH}\right) \mathrm{NCH}_{2} \mathrm{CH}_{2} \mathrm{~N}=\mathrm{CH}-\left(2-\mathrm{O}, 4-\mathrm{CO}_{2} \mathrm{H}_{-}-\mathrm{C}_{6} \mathrm{H}_{3}\right)\right\}\right]$}

To a Schlenk tube containing a stirred solution of half unit $1(100 \mathrm{mg}, 0.26 \mathrm{mmol})$ in ethanol $(50 \mathrm{~mL})$ was added dropwise 4-formyl-3-hydroxybenzoic acid (43 $\mathrm{mg}, 0.26 \mathrm{mmol})$ in ethanol $(10 \mathrm{~mL})$. The resulting solution was stirred for $15 \mathrm{~min}$ at room temperature. Then, a solution of palladium acetate $(58 \mathrm{mg}, 0.26 \mathrm{mmol})$ in ethanol $(10 \mathrm{~mL})$ was added and the resulting solution was refluxed for $2 \mathrm{~h}$. A yellow microcrystalline precipitate formed. The reaction mixture was cooled down to room temperature and the solid material was collected by filtration, washed with cold methanol and diethyl ether $(2 \times 5 \mathrm{~mL})$, and dried under vacuum. Yield: $142 \mathrm{mg}, 86 \%$. X-ray quality crystals of 3 were obtained by slow diffusion of diethyl ether into a solution of the complex in DMF/methanol (1:1). Elemental analysis (\%) calculated for $\mathrm{C}_{29} \mathrm{H}_{24} \mathrm{FeN}_{2} \mathrm{O}_{5} \mathrm{Pd} \cdot 2 \mathrm{H}_{2} \mathrm{O}\left(678.2 \mathrm{~g} \mathrm{~mol}^{-1}\right)$ : C, 51.31; H, 4.16; N, 4.13. Found: $\mathrm{C}, 50.72 ; \mathrm{H}$, 3.85; N, 4.00. IR (KBr, cm-1): 3435(s) v(O-H), 3090(w), 3030(w) v(C-H arom), 2960(w), 
2915(m), 2861(w) v(C-H aliph), 1674 (m) v(C=O), 1625 (m), 1610 (s) v(C $\cdots \mathrm{O}), v(\mathrm{C} \cdots \mathrm{C})$ and/or $v(\mathrm{C}-\mathrm{N}), 1264(\mathrm{~m}) v(\mathrm{C}-\mathrm{O}) .{ }^{1} \mathrm{H}$ NMR $\left(400 \mathrm{MHz},\left(\mathrm{CD}_{3}\right)_{2} \mathrm{SO}\right): \delta_{\mathrm{H}} 3.33\left(\right.$ br t, ${ }^{3} J_{\mathrm{H}, \mathrm{H}}=5.6 \mathrm{~Hz}, 2 \mathrm{H}$, $\mathrm{NCH}_{2}$ ), 3.74 (br t, ${ }^{3} \mathrm{~J}_{\mathrm{H}, \mathrm{H}}=5.6 \mathrm{~Hz}, 2 \mathrm{H}, \mathrm{CH}_{2} \mathrm{~N}$ ), $4.15\left(\mathrm{~s}, 5 \mathrm{H}, \mathrm{C}_{5} \mathrm{H}_{5}\right), 4.35$ (br t, $2 \mathrm{H}, \mathrm{H}_{\beta} \mathrm{C}_{5} \mathrm{H}_{4}$ ), 4.70 (br t, $2 \mathrm{H}, \mathrm{H}_{\alpha} \mathrm{C}_{5} \mathrm{H}_{4}$ ), 5.35 (s, $\left.1 \mathrm{H}, \mathrm{CH}=\mathrm{C}\right), 6.87$ (d, $\left.{ }^{3} \mathrm{~J}_{\mathrm{H}, \mathrm{H}}=8.0 \mathrm{~Hz}, 2 \mathrm{H}, o-\mathrm{PhOH}\right), 7.06$ (d, $\left.{ }^{3} J_{\mathrm{H}, \mathrm{H}}=7.6 \mathrm{~Hz}, 1 \mathrm{H}, \mathrm{H}-5\right), 7.25\left(\mathrm{~d},{ }^{3} J_{\mathrm{H}, \mathrm{H}}=8.0 \mathrm{~Hz}, m-\mathrm{PhOH}\right), 7.39(\mathrm{~s}, 1 \mathrm{H}, \mathrm{H}-3), 7.48\left(\mathrm{~d},{ }^{3} J_{\mathrm{H}, \mathrm{H}}=\right.$ $7.6 \mathrm{~Hz}, 1 \mathrm{H}, \mathrm{H}-6), 8.24$ (br s, $1 \mathrm{H}, \mathrm{N}=\mathrm{CH}), 9.84$ (br s, $1 \mathrm{H}, \mathrm{OH}) .{ }^{13} \mathrm{C}\left\{{ }^{1} \mathrm{H}\right\} \mathrm{NMR}(100 \mathrm{MHz}$, $\left.\left(\mathrm{CD}_{3}\right)_{2} \mathrm{SO}\right): \delta_{\mathrm{C}} 55.58\left(\mathrm{NCH}_{2}\right), 61.36\left(\mathrm{CH}_{2} \mathrm{~N}\right), 68.03\left(\mathrm{C}_{\alpha} \mathrm{C}_{5} \mathrm{H}_{4}\right), 69.63\left(\mathrm{C}_{5} \mathrm{H}_{5}\right), 69.78\left(\mathrm{C}_{\beta} \mathrm{C}_{5} \mathrm{H}_{4}\right)$, $81.84\left(\mathrm{C}_{\mathrm{ipso}} \mathrm{C}_{5} \mathrm{H}_{4}\right), 96.74(\mathrm{CH}=\mathrm{C}), 113.88(\mathrm{C}-5), 115.18(\mathrm{CH} o-\mathrm{C} \mathrm{PhOH}), 121.56(\mathrm{C}-3), 123.82$ (C-1), 127.64 ( $\left.\mathrm{C}_{\text {ipso }} \mathrm{PhOH}\right), 128.47$ (CH m-C PhOH), 134.68 (C-6), 135.78 (C-4), 157.81 ( $\mathrm{C}_{\text {ipso }}$ $\mathrm{C}-\mathrm{OH}), 159.98(\mathrm{~N}=\mathrm{CH}), 163.02(\mathrm{CH}=C), 164.32(\mathrm{C}-2), 167.46\left(\mathrm{CO}_{2} \mathrm{H}\right), 175.37(\mathrm{C}=\mathrm{O})$.

Synthesis of $\quad\left[\mathrm{Pd}\left\{\mathrm{Fc}-\mathrm{C}(=\mathrm{O}) \mathrm{CH}=\mathrm{C}\left(4-\mathrm{C}_{6} \mathrm{H}_{4} \mathrm{OH}\right) \mathrm{NCH}_{2} \mathrm{CH}_{2} \mathrm{~N}=\mathrm{CH}-\left(2-\mathrm{O}-\left(\eta^{6}-\right.\right.\right.\right.$ $\left.\left.\left.\left.\mathrm{C}_{6} \mathrm{H}_{4}\right) \mathrm{RuCp}^{*}\right)\right\}\right] \mathrm{PF}_{6}$ (4)

The synthesis of this red microcrystalline complex $\mathbf{4}$ was carried out following a similar procedure to that described above for $\mathbf{3}$, using in this case $100 \mathrm{mg}(0.26 \mathrm{mmol})$ of half unit $\mathbf{1}$, $129 \mathrm{mg}(0.26 \mathrm{mmol})$ of $\left[\mathrm{Cp} * \mathrm{Ru}\left(\eta^{6}-2-\mathrm{HO}-\mathrm{C}_{6} \mathrm{H}_{4} \mathrm{CHO}\right)\right] \mathrm{PF}_{6}$ and $58 \mathrm{mg}(0.26 \mathrm{mmol})$ of palladium acetate. Yield: $186 \mathrm{mg}, 74 \%$. X-ray quality crystals of 4 were obtained by slow diffusion of diethyl ether into a solution of the complex in DMF/methanol (2:1). Elemental analysis (\%) calculated for $\mathrm{C}_{38} \mathrm{H}_{3}{ }_{9} \mathrm{~F}_{6} \mathrm{FeN}_{2} \mathrm{O}_{3} \mathrm{PPdRu} \cdot \mathrm{H}_{2} \mathrm{O}\left(998.1 \mathrm{~g} \mathrm{~mol}^{-1}\right)$ : C, 45.73; H, 4.14; N, 2.81; found C 45.63; H, 3.86; N, 2.50. IR (KBr, $\left.\mathrm{cm}^{-1}\right): 3444(\mathrm{w}) v(\mathrm{O}-\mathrm{H}), 3084(\mathrm{vw}) v(\mathrm{C}-\mathrm{H}$ arom), 2964 (vw), 2912 (vw), 2862 (vw) v(C-H aliph), 1650 (m), 1610 (m), 1562 (w) v(C - O ), v(C -C) and/or $v(\mathrm{C}-\mathrm{N}), 844(\mathrm{vs}) v\left(\mathrm{PF}_{6}\right), 558(\mathrm{~m}) \delta(\mathrm{P}-\mathrm{F}) .{ }^{1} \mathrm{H}$ NMR $\left(500 \mathrm{MHz},\left(\mathrm{CD}_{3}\right)_{2} \mathrm{SO}\right): \delta_{\mathrm{H}} 1.91(\mathrm{~s}$, $\left.15 \mathrm{H}, \mathrm{C}_{5}\left(\mathrm{CH}_{3}\right)_{5}\right), 3.35$ and $3.42\left(2 \times \mathrm{m}, 2 \times 1 \mathrm{H}, \mathrm{NCH}_{2}\right), 3.77$ and $3.84\left(2 \times \mathrm{m}, 2 \times 1 \mathrm{H}, \mathrm{CH}_{2} \mathrm{~N}\right)$, $4.15\left(\mathrm{~s}, 5 \mathrm{H}, \mathrm{C}_{5} \mathrm{H}_{5}\right), 4.37$ and $4.38\left(2 \mathrm{x}\right.$ br s, $2 \times 1 \mathrm{H}, \mathrm{H}_{\beta}$ and $\left.\mathrm{H}_{\beta}, \mathrm{C}_{5} \mathrm{H}_{4}\right), 4.68$ and $4.73(2 \mathrm{x}$ br s, $2 \times 1 \mathrm{H}, \mathrm{H}_{\alpha}$ and $\left.\mathrm{H}_{\alpha}, \mathrm{C}_{5} \mathrm{H}_{4}\right), 5.40(\mathrm{~s}, 1 \mathrm{H}, \mathrm{CH}=\mathrm{C}), 5.74\left(\mathrm{~d},{ }^{3} J_{\mathrm{H}, \mathrm{H}}=6.3 \mathrm{~Hz}, 1 \mathrm{H}, \mathrm{H}-3\right), 5.77(\mathrm{t}$, $\left.{ }^{3} J_{\mathrm{H}, \mathrm{H}}=5.9 \mathrm{~Hz}, 1 \mathrm{H}, \mathrm{H}-4\right), 5.90\left(\mathrm{t},{ }^{3} J_{\mathrm{H}, \mathrm{H}}=5.9 \mathrm{~Hz}, 1 \mathrm{H}, \mathrm{H}-5\right), 5.98\left(\mathrm{~d},{ }^{3} J_{\mathrm{H}, \mathrm{H}}=5.5 \mathrm{~Hz}, 1 \mathrm{H}, \mathrm{H}-6\right)$, $6.89\left(\mathrm{~d},{ }^{3} J_{\mathrm{H}, \mathrm{H}}=8.4 \mathrm{~Hz}, 2 \mathrm{H}, o-\mathrm{C}_{6} \mathrm{H}_{4} \mathrm{OH}\right), 7.28\left(\mathrm{~d},{ }^{3} J_{\mathrm{H}, \mathrm{H}}=8.4 \mathrm{~Hz}, 2 \mathrm{H}, m-\mathrm{C}_{6} \mathrm{H}_{4} \mathrm{OH}\right), 8.27(\mathrm{~s}, 1$ $\left.\mathrm{H}, \mathrm{N}=\mathrm{CH}), 9.87(\mathrm{~s}, 1 \mathrm{H}, \mathrm{OH}) .{ }^{13} \mathrm{C}\left\{{ }^{1} \mathrm{H}\right\} \mathrm{NMR}\left(125 \mathrm{MHz}, \mathrm{CD}_{3}\right)_{2} \mathrm{SO}\right): \delta \mathrm{C} 9.96\left(\mathrm{C}_{5}\left(\mathrm{CH}_{3}\right) 5\right), 55.80$ $\left(\mathrm{NCH}_{2}\right), 62.35\left(\mathrm{CH}_{2} \mathrm{~N}\right), 67.60$ and $68.59\left(\mathrm{C}_{\alpha}\right.$ and $\left.\mathrm{C}_{\alpha}{ }^{\prime} \mathrm{C}_{5} \mathrm{H}_{4}\right), 69.67\left(\mathrm{C}_{5} \mathrm{H}_{5}\right), 69.95$ and $70.02\left(\mathrm{C}_{\beta}\right.$ and $\left.\mathrm{C}_{\beta}, \mathrm{C}_{5} \mathrm{H}_{4}\right), 81.23\left(\mathrm{C}_{\text {ipso }} \mathrm{C}_{5} \mathrm{H}_{4}\right), 78.15$ (C-3), 80.64 (C-1), 83.76 (C-5), 88.87 (C-4 and C-6), 93.88 $\left(\mathrm{C}_{5}\left(\mathrm{CH}_{3}\right) 5\right), 96.97(\mathrm{CH}=\mathrm{C}), 115.20(\mathrm{Co}-\mathrm{PhOH}), 126.99\left(\mathrm{C}_{\mathrm{ipso}} \mathrm{PhOH}\right), 128.61(m-\mathrm{PhOH})$, $139.63(\mathrm{C}-2), 158.02(\mathrm{C}-\mathrm{OH}), 163.11(\mathrm{CH}=\mathrm{C}), 163.67(\mathrm{~N}=\mathrm{CH}), 175.53(\mathrm{C}=\mathrm{O})$. 


\section{X-ray Crystal Structure Determinations}

An orange prism-shaped single-crystal of $\mathbf{3} \cdot \mathrm{H}_{2} \mathrm{O}$ of suitable dimensions was coated in Paratone-N oil, mounted on a Kaptan loop and transferred to the cold gas stream of the cooling device. Intensity data were collected at $\mathrm{T}=150(2) \mathrm{K}$ on a APEXII Bruker-AXS diffractometer, equipped with a CCD plate detector using graphite monochromated Mo-K $\alpha$ radiation $(\lambda=$ $0.71073 \AA$ ), and were corrected for absorption effects using multiscanned reflections. The structure was solved by direct methods using the $\operatorname{SIR} 97$ program, ${ }^{62}$ and refined with full-matrix least-square methods based on F2 (SHELXL-2014). ${ }^{63}$ A clear orange block shaped singlecrystal of the trimetallic complex $\mathbf{4}$ was mounted on the top of glass fibers in a random orientation. Diffraction data were collected at 296(2) K on a Bruker D8 QUEST diffractome ter equipped with a bidimensional CMOS Photon100 detector, using graphite monochromated Mo$\mathrm{K} \alpha$ radiation $(\lambda=0.71073 \AA)$. The diffraction frames were integrated using the APEX3 package, ${ }^{64}$ and were corrected for absorptions with SADABS. The structure was solved by direct methods using the Olex 2 program. ${ }^{65}$ The structure was refined with full-matrix leastsquare methods based on $F^{2}(S H E L X L-2018 / 1) .{ }^{63}$ For compound 4, the unsubstituted cyclopentadienyl group exhibit a rotational disorder in a 50:50 ratio. The cyclopentadienyl rings were idealized using rigid pentagon group with $1.42 \AA$ bond distance (AFIX 55). Likewise, the hexafluorophosphate counterion presents a positional disorder with a refined 70:30 occupancies. The modelization for these groups was built using SADI to set all 1,2- and 1,3bond distances to be the same for each pair of atoms. EADP instructions were applied to constrain the anisotropic ellipsoid displacements to be the same in both fragments. Additionally, for hexafluorophosphate anion, ISOR instruction was used in order to approximate the thermal ellipsoids components to isotropic behavior. In both cases, all non-hydrogen atoms were refined with anisotropic atomic displacement parameters. Except hydrogen atoms linked to oxygen atoms in complex $3 \cdot \mathrm{H}_{2} \mathrm{O}$ that were introduced in the structural model through Fourier difference maps analysis, $\mathrm{H}$ atoms in both $\mathbf{3} \cdot \mathrm{H}_{2} \mathrm{O}$ and $\mathbf{4}$ were placed in their geometrically idealized positions and constrained to ride on their parent atoms. A summary of the details about crystal data, collection parameters and refinement are documented in Table 6, and additional crystallographic details are in the CIF files. ORTEP views are drawn using Olex 2 software. ${ }^{65}$

Table 6 Crystallographic data, details of data collection and structure refinement parameters for compounds $\mathbf{3} \cdot \mathrm{H}_{2} \mathrm{O}$ and $\mathbf{4}$. 


\begin{tabular}{|c|c|c|}
\hline & $3 \cdot \mathrm{H}_{2} \mathrm{O}$ & 4 \\
\hline Empirical Formula & $\mathrm{C}_{29} \mathrm{H}_{26} \mathrm{FeN}_{2} \mathrm{O}_{6} \mathrm{Pd}$ & $\mathrm{C}_{38} \mathrm{H}_{39} \mathrm{~F}_{6} \mathrm{FeN}_{2} \mathrm{O}_{3} \mathrm{PPdRu}$ \\
\hline Formula mass, $\mathrm{g} \mathrm{mol}^{-1}$ & 660.77 & 980.00 \\
\hline Collection $\mathrm{T}, \mathrm{K}$ & $150(2)$ & $296(2)$ \\
\hline Crystal system & triclinic & monoclinic \\
\hline Space group & $\mathrm{P}-1$ & $\mathrm{P} 2{ }_{1} / \mathrm{n}$ \\
\hline$a(\AA)$ & $7.2722(3)$ & $12.2768(4)$ \\
\hline$b(\AA)$ & $12.5064(5)$ & $17.7955(5)$ \\
\hline$c(\AA)$ & $14.6658(6)$ & $16.8416(5)$ \\
\hline$\alpha\left({ }^{\circ}\right)$ & $101.630(2)$ & 90 \\
\hline$\beta\left(^{\circ}\right)$ & $90.256(2)$ & $93.1540(10)$ \\
\hline$\gamma\left({ }^{\circ}\right)$ & $102.051(2)$ & 90 \\
\hline$V\left(\AA^{3}\right)$ & $1276.15(9)$ & $3673.84(19)$ \\
\hline$Z$ & 2 & 4 \\
\hline$D_{\text {calcd }}\left(\mathrm{g} \mathrm{cm}^{-3}\right)$ & 1.720 & 1.772 \\
\hline Crystal size (mm) & $0.14 \times 0.06 \times 0.04$ & $0.32 \times 0.14 \times 0.13$ \\
\hline Crystal color & Orange & Orange \\
\hline$F(000)$ & 668 & 1960 \\
\hline $\operatorname{abs} \operatorname{coeff}\left(\mathrm{mm}^{-1}\right)$ & 1.322 & 1.394 \\
\hline$\theta$ range $\left(^{\circ}\right)$ & 1.419 to 27.501 & 2.017 to 26.397 \\
\hline range $h, k, l$ & $-8 / 9,-15 / 16,-19 / 19$ & $-14 / 14,-21 / 21,-21 / 21$ \\
\hline No. total refl. & 16173 & 41994 \\
\hline No. unique refl. & 5788 & 7433 \\
\hline Comp. $\theta_{\max }(\%)$ & 98.6 & 98.6 \\
\hline Max/min transmission & $0.948 / 0.866$ & $0.7454 / 0.6327$ \\
\hline Data/Restraints/Parameters & $5788 / 2 / 364$ & $7433 / 429 / 515$ \\
\hline $\begin{array}{l}\text { Final R } \\
{[I>2 \sigma(I)]}\end{array}$ & $\begin{array}{l}\mathrm{R}_{1}=0.0367 \\
\mathrm{wR}_{2}=0.0935\end{array}$ & $\begin{array}{l}\mathrm{R}_{1}=0.0454 \\
\mathrm{wR}_{2}=0.1038\end{array}$ \\
\hline $\mathrm{R}$ indices (all data) & $\begin{array}{l}\mathrm{R}_{1}=0.0552 \\
\mathrm{wR}_{2}=0.1045\end{array}$ & $\begin{array}{l}\mathrm{R}_{1}=0.0735 \\
\mathrm{wR}_{2}=0.1215\end{array}$ \\
\hline Goodness of fit / $\mathrm{F}^{2}$ & 0.958 & 1.035 \\
\hline Largest diff. Peak/hole $\left(e \AA^{-3}\right)$ & $0.689 /-0.626$ & $1.174 /-0.709$ \\
\hline
\end{tabular}

\section{HLS measurements}

For the second-order NLO measurements of the Schiff-base chromophores 2-4, Harmonic Light Scattering (HLS) ${ }^{60}$ was performed using a $10 \mathrm{~Hz}$ repetition-rate nanosecond $\mathrm{Nd}^{3+}$ :YAG laser coupled to a hydrogen Raman shifter to produce a fundamental wavelength at $1.91 \mu \mathrm{m}$. First-order hyperpolarizabilities $(\beta)$ are inferred from a series of plots of the HLS second harmonic signal emitted by the solution of the molecule under investigation, with 
respect to a reference SHG emission produced by a highly nonlinear N-4-nitrophenyl-1-prolinol crystalline powder Measurements at this $1.91 \mu \mathrm{m}$ fundamental wavelength were carried out with $10^{-2} \mathrm{M}$ solutions of 2-4 in DMF. The solvent appears to be transparent at $1.91 \mu \mathrm{m}$. A concentrated $\left(10^{-2} \mathrm{M}\right)$ solution of ethyl violet (its octupolar $\beta$ value being $170 \times 10^{-30}$ esu at $1.91 \mu \mathrm{m}$ ) was used as external reference. ${ }^{66}$ By using a wavelength of $1.91 \mu \mathrm{m}$, the harmonics at $955 \mathrm{~nm}$ remains far from any resonance of the molecules, then preventing from linear absorption losses of the emitted second harmonic photons, and from the contribution of possible two-photon fluorescence emission to the HLS signal. We verified the absence of any wide-band two-photon fluorescence by checking that no HLS signal could be detected for wavelengths other than $955 \mathrm{~nm}$. The experimental setup and details of data collection and analysis have been described previously. ${ }^{37 a}$

\section{Conflicts of Interest}

The authors declare no conflict of interest.

\section{Acknowledgments}

We thank S. Sinbandhit (CRMPO, Rennes) for helpful assistance with NMR measurements. This research was performed as part of the Chilean-French International Research program "Multifunctional Molecules and Materials" (IRP M3-CNRS No. 1207). Financial support from the Fondo Nacional de Desarrollo Científico y Tecnológico (FONDECYT), Chile (grant 1090310) and FONDEQUIP EQM130154 and EQM120095], the Vicerrectoría de Investigación y Estudios Avanzados, Pontificia Universidad Católica de Valparaíso, Chile (VRIEA-PUCV), the Centre National de la Recherche Scientifique (CNRS) and the Université de Rennes 1 is gratefully acknowledged. S.C. thanks VRIEA-PUCV and FONDECYT for the postdoctoral financing. 
Notes and reference

1 T. T. Tidwell, Angew. Chem. Int. Ed., 2008, 47, 1016-1020.

2 Selected review articles and cited references: (a) J. Yang, R. Shi, P. Zhou, Q. Qiu and H. Li, J. Mol. Struct., 2016, 1106, 242-258; (b) M. Andruh, Dalton Trans., 2015, 44, $16633-$ 16653; (c) M. Rezaeivala and H. Keypour, Coord. Chem. Rev., 2014, 280, 203-253; (d) R. M. Clarke and T. Storr, Dalton Trans., 2014, 43, 9380-9391; (e) C. J. Whiteoak, G. Salassa and A. W. Kleij, Chem. Soc. Rev., 2012, 41, 622-631; (f) P. A. Vigato, V. Peruzzo and S. Tamburini, Coord. Chem. Rev., 2012, 256, 953-1114; (g) W. Radecka-Paryzek, V. Patroniak and J. Lisowski, Coord. Chem. Rev., 2005, 249, 2156-2175; (h) P. A. Vigato and S. Tamburini, Coord. Chem. Rev., 2004, 248, 1717-2128; (i) J. Costamagna, J. Vargas, R. Latorre, A. Alvarado and G. Mena, Coord. Chem. Rev., 1992, 119, 67-88; JR. H. Holm, G.W. Everett, Jr. and A. Chakravorty, Prog. Inorg. Chem., 1966, 7, 83-214.

3 X. Liu and J.-R. Hamon, Coord. Chem. Rev., 2019, 389, 94-118.

4 (a) P. G. Cozy, Chem. Soc. Rev., 2004, 33, 410-421; (b) C. Camp, L. Chatelain, V. Mougel, J. Pécaut and M. Mazzanti, Inorg. Chem., 2015, 54, 5774-5783.

5 (a) S. Matsunaga and M. Shibasaki, Chem. Commun., 2014, 50, 1044-1057; (b) K.C. Gupta and A. K. Sutar, Coord. Chem. Rev., 2008, 252, 1420-1450; (c) D. J. Darensbourg, Chem. Rev., 2007, 107, 2388-2410; (d) E. M. McGarrigle and D. G. Gilheany, Chem. Rev., 2005, 105, 1563-1602.

6 E. L. Gavey and M. Pilkington, Coord. Chem. Rev., 2015, 296, 125-152.

7 (a) B. Weber, Coord. Chem. Rev., 2009, 253, 2432-2449; (b) J. Pavlik, P. Masárová, I. Nemec, O. Fuhr, M. Ruben and I. Šalitroš, Inorg. Chem., 2020, 59, 2747-2757; (c) M. A. Al-Azzani, F. Al-Mjeni, R. Mitsuhashi, M. Mikuriya, I. A. Al-Omari, C. C. Robertson, E. Bill, M. S. Shongwe, Chem. Eur. J., 2020, 26, 4766-4779.

8 T. J. Boyle, J. M. Sears, J. A. Greathouse, D. Perales, R. Cramer, O. Staples, A. L. Rheingold, E. N. Coker, T. M. Roper and R. A. Kemp, Inorg. Chem., 2018, 57, 2402-2415.

9 C. R. Nayar and R. Ravikumar, J. Coord. Chem., 2014, 67, 1-16.

10 (a) S. Di Bella, A. Colombo, C. Dragonetti, S. Righetto and D. Roberto, Inorganics, 2018, 6, 133: doi:10.3390/inorganics6040133; (b) S. Di Bella, C. Dragonetti, M. Pizzotti, D. Roberto, F. Tessore and R. Ugo, in Topics in Organometallic Chemistry 28. Molecular 
Organometallic Materials for Optics, eds. H. Le Bozec and V. Guerchais, Springer-Verlag, Berlin/Heidelberg, 2010, p. 1-55 ; (c) S. Di Bella, Chem. Soc. Rev., 2001, 30, 355-366.

11 (a) P. G. Lacroix, I. Malfant and C. Lepetit, Coord. Chem. Rev., 2016, 308, 381-394; (b) P. G. Lacroix, Eur. J. Inorg. Chem., 2001, 339-348.

12 (a) B. J. Coe, Coord. Chem. Rev., 2013, 257, 1438-1458; (b) O. Maury and H. Le Bozec, in Molecular Materials, Eds. D. W. Bruce, D. O'Hare and R. I. Walton, Metal-Based Quadratic Nonlinear Optical Materials, John Wiley \& Sons, Ltd, Chichester, UK, 2010, Chapter 1, p. 1-59; (c) B. J. Coe and N. R. M. Curati, Comments Inorg. Chem., 2004, 25, 147-184.

13 (a) J. Zhou and B. Wang, Chem. Soc. Rev., 2017, 46, 6927-6945; (b) V. Ganesan and S. Yoon, Inorg. Chem., 2020, 59, 2881-2889.

14 (a) J. Zhang, L. Xu and W.-Y. Wong, Coord. Chem. Rev., 2018, 355, 180-198; (b) C.-M. Che, S.-C. Chan, H.-F. Xiang, M. C. W. Chan, Y. Liu and Y. Wang, Chem. Commun., 2004, 1484-1485.

15 R.-K. Lin, C.-I. Chiu, C.-H. Hsu, Y.-J. Lai, P. Venkatesan, P.-H. Huang, P.-S. Lai and C.C. Lin, Chem. Eur. J., 2018, 24, 4111-4120.

16 Â. de Fátima, C. de Paula Pereira, C. R. Said Dau Gonçalves Olímpio, B. G. de Freitas Oliveira, L. Lopardi Franco and P. H.Corrêa da Silva, J. Adv. Res., 2018, 13, 113-126.

17 T. Mukherjee, J. C. Pessoa, A. Kumar and A. R. Sarkar, Dalton Trans., 2013, 42, 25942607.

18 J. E. Baumeister, K. M. Reinig, C. L. Barnes, S. P. Kelley and S. S. Jurisson, Inorg. Chem., 2018, 57, 12920-12933.

19 R. Golbedaghi and R. Fausto, Polyhedron, 2018, 155, 1-12.

20 P. Das and W. Linert, Coord. Chem. Rev., 2016, 311, 1-23.

21 For homogeneous catalysis, see also: (a) R. Nandhini, G. Venkatachalam, M. D. Kumar and M. Jaccob, Polyhedron, 2019, 158, 183-192; (b) M. Sedighipoor, A. Hossein Kianfar, G. Mohammadnezhad, H. Görls and W. Plass, Inorg. Chim. Acta, 2018, 476, 20-26; (c) A. K. Sharma, H. Joshi, R. Bhaskar, S. Kumar and A. K. Singh, Dalton Trans., 2017,46, 24852496; (d) S. Layek, A. Bhumika Agrahari and D. D. Pathak, J. Organomet. Chem., 2017, 
846, 105-112; (e) Z. Beigi, A. Hossein Kianfar, G. Mohammadnezhad, H. Görls and W. Plass, Polyhedron, 2017, 134, 65-72.

22 For supported catalysis, see also: (a) M. Shaker and D. Elhamifar, New J. Chem., 2020,44, 3445-3454; (b) S. Kumari, K. Maddipoti, B. Das and S. Ray, Inorg. Chem., 2019, 58, 15271540; (c) A. Reza Sardarian, M. Kazemnejadi and M. Esmaeilpour, Dalton Trans., 2019,48, 3132-3145; (d) A. Zarnegaryan, Z. Dehbanipour and D. Elhamifar, Polyhedron, 2019, 170, 530-536; (e) K. R. Balinge, A. i. Ganesh Khiratkar and P. n. Rambhau Bhagat, J. Organomet. Chem., 2018, 854, 131-139; (f) P. Basu, S. Riyajuddin, T. Kanto Dey, A. Ghosh, K. Ghosh and S. Manirul Islam, J. Organomet. Chem., 2018, 877, 37-50; (g) J. Bi , J. Chen, Y. Dong, W. Guo, D. Zhu and T. Li, J. Polym. Sci. Part A: Polym. Chem., 2018, 56, 2344-2353.

23 A. Garoufis, S. K. Hadjikakou and N. Hadjiliadis, Coord. Chem. Rev., 2009, 253, 13841397.

24 M. A. Ali, A. H. Mirza, R. J. Butcher, M.T.H. Tarafder, T. B. Keat and A. M. Ali, J. Inorg. Biochem., 2002, 92, 141-148.

25 F.A. I. Al-Khodir, H. M. A. Abumelha, T. Al-Warhi and S. A. Al-Issa, Biomed Res. Int., 2019 1-14.

26 Z. Faghih, A. Neshat, A. Wojtczak, Z. Faghih, Z. Mohammadi and S. Varestan, Inorg. Chim. Acta, 2018, 471, 404-412.

27 S. Muche, K. Harms, A. Biernasiuk, A. Malm, Ł. Popioek, A. Hordyjewska, A. Olszewska and M. Hołynska, Polyhedron, 2018, 151, 465-477.

28 C. E. Satheesh, P. Raghavendra Kumar, P. Sharma, K. Lingaraju, B. S. Palakshamurthy and H. Raja Naika, Inorg. Chim. Acta, 2016, 442, 1-9.

29 F. Cariati, U. Caruso, R. Centore, W. Marcolli, A. De Maria, B. Panunzi, A. Roviello and A. Tuzi, Inorg. Chem., 2002, 41, 6597-6603.

30 B. J. Rudresha, B. Ramachandra Bhat, D. Ramakrishna, J. K. Anthony, H.W. Lee and F.Rotermund, Opt. Laser Technol., 2012, 44, 1180-1183.

31 R. G. Mohamed, F. M. Elantabli, A. A. Abdel Aziz, H. Moustafa and S. M. El-Medani, J. Mol. Struct., 2019, 1176, 501-514. 
32 S. Celedón, M. Fuentealba, T. Roisnel, I. Ledoux-Rak, J.-R. Hamon, D. Carrillo and C. Manzur, Eur. J. Inorg. Chem., 2016, 3012-3023.

33 (a) L. T. Cheng, W. Tam, S. H. Stevenson, G. R. Meredith, G. Rikken and S. R. Marder, J. Phys. Chem., 1991, 95, 10631-10643; (b) L.-T. Cheng, W. Tam, S. R. Marder, A. E. Stirgman, G. Rikken and C. W. Sprangler, J. Phys. Chem., 1991, 95, 10643-10652.

34 (a) L. Rigamonti, F. Demartin, A. Forni, S. Righetto and A. Pasini, Inorg. Chem., 2006, 45, 10976-10989; (b) J. Gradinaru, A. Forni, V. Druta, F. Tessore, S. Zecchin, S. Quici and N. Garbalau, Inorg. Chem., 2007, 46, 884-895; (c) L. Rigamonti, A. Forni, S. Righetto and A. Pasini, Dalton Trans., 2019, 48, 11217-11234; (d) L. Rigamonti, A. Forni, E. Cariati, G. Malavasi and A. Pasini, Materials, 2019, 12, 3595: doi:10.3390/ma12213595

35 (a) I. González, D. Cortés-Arriagada, P. Dreyse, L. Sanhueza-Vega, I. Ledoux-Rak, D. Andrade, I. Brito, A. Toro-Labbé, M. Soto-Arriaza, S. Caramori and B. Loeb, Eur. J. Inorg. Chem., 2015, 4946-4955; (b) T. Guerrero, P. G. Lacroix, H. García-Ortega, O. G. Morales-Saavedra, D. Agustin and N. Farfán, Inorg. Chim. Acta, 2016, 442, 10-15; (c) A. Boulmier, A. Vacher, D. Zang, S. Yang, A. Saad, J. Marrot, O. Oms, P. Mialane, I. Ledoux, L. Ruhlmann, D. Lorcy, and A. Dolbecq, Inorg. Chem., 2018, 57, 3742-3752; (d) B. Mohan, A. Jana, N. Das, S. Bharti, M. Choudhary, S. Muhammad, S. Kumar, A. G. AlSehemi and H. Algarni, Inorg. Chim. Acta, 2019, 484, 148-159.

36 (a) F. Tessore, D. Roberto, R. Ugo, P. Mussini, S. Quici, I. Ledoux-Rak and J. Zyss, Angew. Chem., Int. Ed., 2003, 42, 456-459; (b) J. Boixel, V. Guerchais, H. Le Bozec, A. Chantzis, D. Jacquemin, A. Colombo, C. Dragonetti, D. Marinotto and D. Roberto, Chem. Commun., 2015, 51, 7805-7808; (c) C. Hierlinger, D. B. Cordes, A. M. Z. Slawin, A. Colombo, C. Dragonetti, S. Righetto, D. Roberto, D. Jacquemin, E. Zysman-Colman and V. Guerchais, Dalton Trans., 2018, 47, 8292-8300;(d) M. Fontani, E. Garoni, A. Colombo, C. Dragonetti, S. Fantacci, H. Doucet, J.-F. Soule, J. Boixel, V. Guerchais and D. Roberto, Dalton Trans., 2019, 48, 202-208; (e) S. Prabu, E. David, T. Viswanathan, K. Thirumoorthy, T. Panda, C. Dragonetti, A. Colombo, D. Marinotto, S. Righetto, D. Roberto and N. Palanisami, Dalton Trans., 2020, 49, 1854-1863.

37 (a) A. Trujillo, M. Fuentealba, D. Carrillo, C. Manzur, I. Ledoux-Rak, J.-R. Hamon and J.-Y. Saillard, Inorg. Chem., 2010, 49, 2750-2764; (b) S. Celedón, V. Dorcet, T. Roisnel, A. Singh, I. Ledoux-Rak, J.-R. Hamon, D. Carrillo and C. Manzur, Eur. J. Inorg. Chem., 2014, 4984-4993; (c) J. Cisterna, V. Dorcet, C. Manzur, I. Ledoux-Rak, J.-R. Hamon and 
D. Carrillo, Inorg. Chim. Acta, 2015, 430, 82-90; (d) N. Novoa, C. Manzur, T. Roisnel, V. Dorcet, N. Cabon, F. Robin-Le Guen, I. Ledoux-Rak, S. Khalal, J.-Y. Saillard, D. Carrillo and J.-R. Hamon, New J. Chem., 2019, 43, 10468-10481.

38 X. Liu, C. Manzur, N. Novoa, S. Celedon, D. Carrillo and J.-R. Hamon, Coord. Chem. Rev., 2018, 357, 144-172.

39 J.-P. Costes, Polyhedron, 1987, 6, 2169-2176 and references cited therein.

40 G. Bett, D. E. Fenton and J. R. Tate, Inorg. Chim. Acta, 1981, 54, L101-L102.

41 S. Celedon, M. Fuentealba, T. Roisnel, J.-R. Hamon, D. Carrillo and C. Manzur, Inorg. Chim. Acta, 2012, 390, 184-189.

42 S. Celedón, T. Roisnel, I. Ledoux-Rak, J.-R. Hamon, D. Carrillo and C. Manzur, J. Inorg. Organomet. Polym. Mater., 2017, 27, 795-804.

43 A. Trujillo, S. Sinbandhit, L. Toupet, D. Carrillo, C. Manzur and J.-R. Hamon, J. Inorg. Organomet. Polym. Mater., 2008, 18, 81-99.

44 J.-P. Costes, F. Z. Chiboub Fellah, F. Dahan and C. Duhayon, Polyhedron, 2013, 52, 10651072 .

45 D. E. Wheeler, N. W. Baetz, G. N. Holder, S. T. Hill, S. Milos and K. A. Luczak, Inorg. Chim. Acta, 2002, 328, 210-217.

46 M. Fuentealba, J.-R. Hamon, D. Carrillo and C. Manzur, New J. Chem., 2007, 31, 18151825.

47 S. M. Hubig, S. V. Lindeman and J. K. Kochi, Coord. Chem. Rev., 2000, 200-202, 831873.

$48 \tau_{4}=0$ for a perfect square planar geometry; L. Yang, D. R. Powell and R. P. Houser, Dalton Trans., 2007, 955-964.

49 (a) H. Kargar, V. Torabi, A. Akbari, R. Behjatmanesh-Ardakani and M. N. Tahir, J. Mol. Struct., 2019, 1179, 732-738; (b) H. Kargar, V. Torabi, A. Akbari, R. BehjatmaneshArdakani, A. Sahraei and M. N. Tahir, J. Mol. Struct., 2020, 1205, 127642.

50 L. E. Sarto, W. Pereira Duarte Badaro, E. Pereira de Gois, M. I. Frazao Barbosa, C. Torres, R. Bezerra Viana, J. Honorato, E. E. Castellano and E. Tonon de Almeida, J. Mol. Struct., 2020, 1204, 127549. 
51 F. H. Allen, O. Kennard, D. G. Watson, L. Brammer, A. G. Orpen and R. Taylor, J. Chem. Soc., Perkin Trans., 1987, S1-S19.

52 (a) F. Averseng, P. G. Lacroix, I. Malfant, G. Lenoble, P. Cassoux, K. Nakatani, I. MalteyFanton, J. A. Delaire and A. Aukauloo, Chem. Mater., 1999, 11, 995-1002; (b) L. Ding, W. Jin, Z. Chu, L. Chen, X. Lü, G. Yuan, J. Song, D. Fan and F. Bao, Inorg. Chem. Commun., 2011, 14, 1274-1278; (c) H. Wang, F. Liu, Y. Yang, M. Zhang, C. Peng, S. Bo, X. Liu, L. Qiu and Z. Zhen, New J. Chem., 2015, 39, 1038-1044.

53 P. Zanello, in Ferrocenes, Eds. A. Togni and T. Hayashi, VCH, New York, 1995, Ch 7, pp. 317-430.

54 (a) B. J. Coe, S. P. Foxon, R. A. Pilkington, S. Sánchez, D. Whittaker, K. Clays, G. Depotter and B. S. Brunschwig, Organometallics, 2015, 34, 1701-1715; (b) B. J. Coe, J. Fielden, S. P. Foxon, I. Asselberghs, K. Clays, S. Van Cleuvenbergen and B. S. Brunschwig, Organometallics, 2011, 30, 5731-5743.

55 S. Kaur, M. Kaur, P. Kaur, K. Clays and K. Singh, Coord. Chem. Rev., 2017, 343, 185219.

56 C. Lopez, R. Bosque, X. Solans, M. Font- Bardía, D. Tramuns, G. Fern and J. Silver, J. Chem. Soc., Dalton Trans., 1994, 3039-3046.

57 (a) D. Anu, P. Naveen, N. P. Rath and M.V. Kaveri, J. Mol. Struct., 2020, 1206, 127703;

(b) O. Ozdemir, P. Gürkan, Y. D. Simay Demir and M. Ark, J. Mol. Struct., 2020, 1207, 127852; (c) S. A. Aboafia, S. A. Elsayed, A. K. A. El-Sayed and A. M. El-Hendawy, J. Mol. Struct., 2018, 1158, 39-50; (d) S. A. Elsayed, I. S. Butler, B. J. Claude and S. I. Mostafa, Trans. Met. Chem., 2015, 40, 179-187.

58 N. Novoa, T. Roisnel, P. Hamon, S. Kahlal, C. Manzur, H.M. Ngo, I. Ledoux-Rak, J.-Y. Saillard, D. Carrillo and J.-R. Hamon, Dalton Trans., 2015, 44, 18019-18037.

59 P. G. Lacroix, S. Di Bella and I. Ledoux, Chem. Mater., 1996, 8, 541-545.

60 R. W. Terhune, P. D. Maker and C. M. Savage, Phys. Rev., 1965, 14, 681-684.

61 W. L. F. Armarego and C. Chai, Purification of Laboratory Chemicals, 7th ed., Elsevier, Ámsterdam, the Netherlands, 2012.

62 A. Altomare, M. C. Burla, M. Camalli, G. L. Cascarano, C. Giacovazzo, A. Guagliardi, A. G. Moliterni, G. Polidori and R. Spagna, J. Appl. Crystallogr., 1999, 32, 115-119. 
63 G. M. Sheldrick, Acta Crystallogr. Sect. C, 2015, 71, 3-8.

64 APEX2, Bruker AXS Inc., Madison, Wisconsin, USA, 2007.

65 O. V. Dolomanov, L. J. Bourhis, R. J. Gildea, J. A. K. Howard and H. Puschmann, J. Appl. Crystallogr., 2009, 42, 339-341.

66 H. Le Bozec, T. Le Bouder, O. Maury, A. Bondon, I. Ledoux, S. Deveau and J. Zyss, Adv. Mater., 2001, 13, 1677-1681. 